\title{
Innovation and employee injury risk in automotive disassembly operations
}

\author{
Neumann, W. Patrick; Winkel, Jørgen; Palmerud, Gunnar; Forsman, Mikael
}

Published in:

International Journal of Production Research

Link to article, DOI:

$10.1080 / 00207543.2018 .1432910$

Publication date:

2018

Document Version

Peer reviewed version

Link back to DTU Orbit

Citation $(A P A)$ :

Neumann, W. P., Winkel, J., Palmerud, G., \& Forsman, M. (2018). Innovation and employee injury risk in automotive disassembly operations. International Journal of Production Research, 56(9), 3188-3203 . https://doi.org/10.1080/00207543.2018.1432910

\section{General rights}

Copyright and moral rights for the publications made accessible in the public portal are retained by the authors and/or other copyright owners and it is a condition of accessing publications that users recognise and abide by the legal requirements associated with these rights.

- Users may download and print one copy of any publication from the public portal for the purpose of private study or research.

- You may not further distribute the material or use it for any profit-making activity or commercial gain

- You may freely distribute the URL identifying the publication in the public portal 


\section{Innovation and employee injury risk in automotive disassembly operations}

W. Patrick Neumann ${ }^{a^{*}}$, Jørgen Winkel ${ }^{\text {b,c }}$, Gunnar Palmerud ${ }^{d \dagger}$, Mikael Forsman ${ }^{\text {e,f }}$

${ }^{a}$ Department of Mechanical and Industrial Engineering, Ryerson University, Toronto,

Canada

${ }^{b}$ Department of Sociology and Work Science, University of Gothenburg, P. O. Box 720, SE40530 Gothenburg, Sweden

${ }^{c}$ Department of Management Engineering, Technical University of Denmark, Denmark

${ }^{d}$ Occupational and Environmental Medicine, University of Gothenburg, Sweden

${ }^{e}$ Institute of Environmental Medicine, Karolinska Institutet, Stockholm, Sweden

${ }^{f}$ Centre for Musculoskeletal Research, University of Gävle, Sweden

*Corresponding author.E-mail: pneumann@ryerson.ca

Phone: +1 $4169795000 \times 7738$

$\dagger$ Deceased in August 2016 


\begin{abstract}
Engineering innovations in car disassembly systems are studied for affects on system operators' risk of repetitive strain injury (RSI). Objective instrumented measures of injury risk factors with synchronized video-based task analyses were used to examine changes in operators' RSI risk during two cases of engineering innovation: 1) a shift in industrial model from traditional extracting saleable parts to line-based full material recovery, and 2) the prospective effects of a simulated "Lean" inspired process improvement in the line system. Both cases of innovation showed significantly increased movement speeds and reduced muscular recovery opportunities, implying increased RSI risk. This case study reveals a mechanism by which innovation may increase RSI risks for operators. Managers responsible for engineering innovation should ensure their teams have the tools and mandate necessary to control injury hazards as part of the development and design process. These cases suggest how failure to manage RSI hazards in the innovation process may allow increases of injury risks that can compromise operational performance. This "innovation pitfall" has implications for operator health and organizational sustainability. Alternative pathways are discussed.
\end{abstract}

Keywords: Corporate social sustainability, ergonomics, human factors, rationalisation, manufacturing, physical workload, back-track factory, engineering design 


\section{Introduction}

Environmental, legislative, and economic aspects have contributed to increased researcher attention to product disassembly in both product design (e.g. Giri, and Kanthababu, 2015) and system design (e.g. Güngör and Gupta, 2002; Paksoy et al., 2013). Similarly, attention to the human consequences of engineering design choices - ergonomics - has also been given increasing attention in engineering research (eg. Battini et al., 2016; Grosse et al., 2015). Despite this attention, injuries and ill health caused by the design of work, such as repetitive strain disorders, which are the focus of this study, remain a serious problem with costs rivalling those of all cancers combined (Leigh, 2011; Leigh et al., 1997). As many as 1 in 5 working people suffer from work related musculoskeletal pain (Vézina et al., 2011). These design flaws are also associated with negative effects on production quality and financial performance (Erdinç and Yeaow, 201; Rose et al., 2013; Genaidy et al., 2002). Attention to human factors in production system innovation, therefore, remains an area of considerable concern from human wellbeing and system performance perspectives (Jin et al., 2016, Neumann and Dul, 2010).

The problem of RSI and operator wellbeing is inherent to the design of the operations system, which determines the operator's exposure to injury risk factors (Neumann et al., 2006; Battini et al., 2016). RSI hazards appear to be an undesirable by-product of the innovation process itself (Neumann et al., 2002, 2006; Westgaard and Winkel, 2011; Neumann and Village, 2012; Shoaf et al.1997). This issue was raised in the present journal (Kazmierczak et al., 2004) and later further anchored in a comprehensive review of case studies (Westgaard and Winkel 2011). This study examines engineering innovation at the level of: 1) industrialisation strategy for automobile recycling, and 2) process innovation by examining the potential impacts of an efficiency improvement effort to remove "waste" activities. We note that these issues have been much more widely studied in assembly operations than in disassembly systems.

The car recycling industry is poised to undergo extensive industrial development as requirements to recover materials from end-of-life vehicles (EOVs) have been rapidly increasing according to the End of Life Vehicle (ELV) Directive in the EU (2000/53/EC). While shredding and separation approaches are being considered, these separation techniques 
are technically limited and concerns with toxic "shredder fluff" remain (Vermeulen et al., 2012; Vermeulen et al., 2011). An alternative approach is the manual dismantling of cars into component materials - which can then be sold as "clean" materials (Car Recycling Services, B.V.) This approach is an innovation from the commonly used recycling strategy, in which cars are drained of toxic fluids as required by law, and component parts with value are extracted for re-sale. The new system includes new carriers, different work organisation, and a different business model. In this paper we use instrumented data of worker kinematics from the innovative line-based disassembly system and compare it to data previously collected by Kazmierczak et al., (2005) on the traditional "parts recovery" model. Our first research question therefore is: How does this innovation in industrialisation strategy of disassembly affect the injury risk for system operators? (RQ1)

Our second examination of hazards associated with engineering innovation is conducted in a simulation of the removal of non-value added "waste" time as promoted by, for example, the "Lean" approach (e.g. Thürer et al., 2017). We side-step here a protracted discussion of the definition of Lean and rather emphasise the mechanical "waste reduction" aspects of process innovation efforts. This is in contrast to the more holistic and worker centred philosophy of the Toyota Production System as described, for example, by Liker (2004). Many studies have found an increase in ill health and injuries associated with "Lean" Implementations (Koukoulaki, 2014; Landsbergis et al., 1999; Westgaard and Winkel, 2011). While there are plenty of criticisms of "Lean" (Carter et al., 2013; Johansson and Abrahamsson, 2009;

Williams et al., 1992), there is little empirical evidence shedding light on the mechanism of how RSI hazards are affected by "waste removal" efforts. This examination addresses the $2^{\text {nd }}$ research question: How can applying a Lean inspired "waste removal" innovation strategy affect the injury risk of system operators in this case? (RQ2). While RQ1 aims at comparing two extant industrialisation models of car disassembly (a retrospective issue), RQ2 provides a nested case study of the possible effects of process innovation in the new line-based system (a prospective issue).

\section{Methods}

In addressing RQ 1, we focus on two aspects of operators' workload in the traditional and serial flow line based dismantling systems. First, we examine time utilization across tasks to 
better understand how the work tasks have changed between the industrialization strategies. Secondly, we compare the kinematic profiles obtained from instrumented sensors measuring system operators' limb movements while working. While complete data is included in the appendix, allowing comparison to future system design approaches, we focus here on the velocity and movement indicators as they are related to the key risk factor of repetitiveness associated with RSI type injuries (National Research Council, 2001; Bernard, 1997; Wells et al., 2007; Nordander et al., 2013).

In addressing RQ2, we focus on the serial line disassembly system in terms of time utilization at the task level and isolate the operators' body-kinematic profiles for each task type (e.g. direct, indirect etc.) using the synchronized video task analysis. This then allows for the calculation of the potential effects of changes in task mix as the "Lean" waste removal efforts proceed. The details of this approach now follow.

\subsection{Serial-flow and traditional car disassembly systems}

Figure 1 illustrates the two systems that are compared in this study. In the serial-flow system fluids, air-bags, battery and wheels were removed before the chassis was transported on a fork-lift truck to the disassembly hall line. Those previously published results are used as reference to the present data set obtained from investigation of a serial-flow car disassembly system. This system included five workstations, with two workers per station; one on each side of the car. At stations 1-3 the glass, rubber, and interior (foam, plastics) were disassembled (Figure 1a). At station 4 (Figure 1b, c), the car was rotated and the engine and gearbox was unfastened, and at the fifth station the engine and gearbox were lifted out. The cycle time was not pre-set; instead a button was pushed to start line movement for all stations. The observed cycle times during the week of data collection ranged from 10 to 20 minutes.

In the traditional systems, as described by Kazmierczak et al., (2004, 2005), most of the working time the workers dismantled valuable parts from insurance cars, generally implying cycle times of 3 to 16 hours. This work included administration i.e. assessing, tagging and categorising the parts (Figure 1d and e). The production output from the traditional systems was thus mainly limited to the extraction of valuable spare parts, in contrast to the serial-flow system producing which aimed at complete dismantling of the vehicle into component material streams for re-use. 

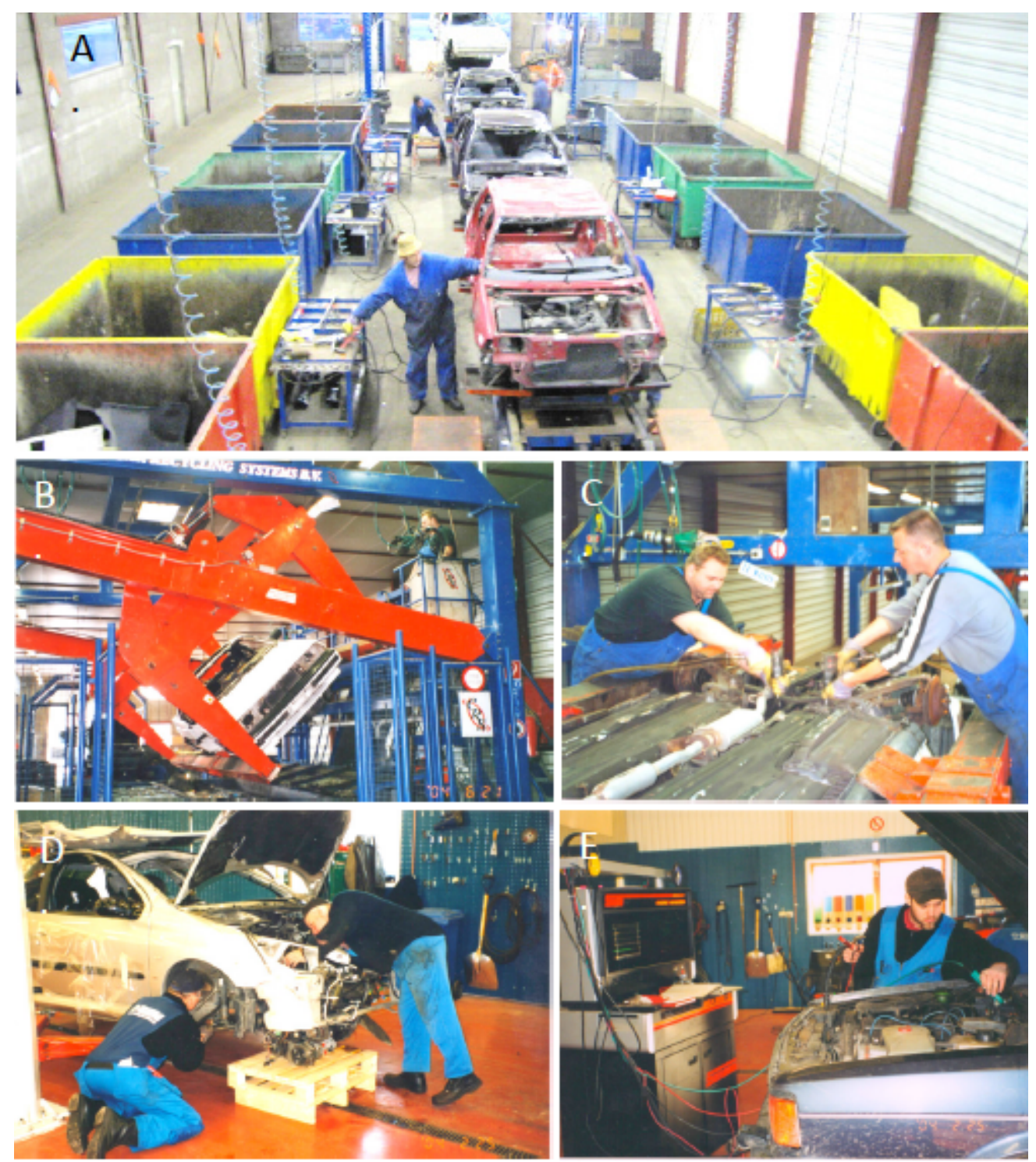

Figure 1. A-C: Examples of disassembly tasks from the present investigated serial-flow system where "end of life" cars are disassembled. D-E: Previously investigated traditional Swedish system.

\subsection{Subjects}

Nine male workers in the serial-flow system participated in the study. The workers were all without previous or present shoulder-neck or arm-hand disorders. The mean experience time in disassembly work was 6.3 yrs. (3.5 months - 14 yrs.). The age ranged from 28 to 43 yrs., weight $67-150 \mathrm{~kg}$, and stature $175-190 \mathrm{~cm}$. They were informed about the experimental procedure before giving their informed consent to participate. The corresponding traditional system data set included data from 10 male workers, two from each of five companies, 21-57 
yrs., $73-88 \mathrm{~kg}, 165-186 \mathrm{~cm}$, with a minimum of 1 year of work experience in car disassembly. All subjects were right-handed.

\subsection{Data collection}

Work activities data and mechanical exposures were collected during an ordinary working day by means of video recordings and synchronised direct technical measurements. Each worker was recorded for about six hours of work (planned breaks excluded).

\subsubsection{Activity analyses}

The work activities were assessed from the video recordings of the subjects during work and classified into five categories (Table 1). A reliability check found the difference between the results of two observers was below $3.7 \%$ for the overall time proportions for four activity categories, and their second-to-second classification disagreed for $13 \%$ of the total analysis time. The between-observer variance was small in comparison to the variance between subjects performing the same job (Kazmierczak et al., 2006).

Table 1. The job of the car dismantlers was classified into five task categories belonging to three main task categories, as shown in the Table.

\begin{tabular}{cccc}
\hline $\begin{array}{c}\text { Work } \\
\text { categories }\end{array}$ & $\begin{array}{c}\text { Task } \\
\text { Category }\end{array}$ & Description \\
\hline $\begin{array}{c}\text { Operations } \\
\text { management }\end{array}$ & $\begin{array}{c}\text { Terminology } \\
\text { 'Lean' }\end{array}$ & $\begin{array}{c}\text { Categories } \\
\text { used in task }\end{array}$ & \\
Terminology & (Liker 2004) & analyses & \\
(Wild 1995) & & & \\
\hline
\end{tabular}

$\begin{array}{cccc}\begin{array}{c}\text { Direct work } \\ \text { (DW) }\end{array} & \begin{array}{c}\text { Value- } \\ \text { adding work } \\ \text { (VAW) }\end{array} & \text { DW } & \begin{array}{l}\text { Disassembly activities. Unscrewing parts, } \\ \text { hammering, tearing, and reaching for a tool } \\ \text { without having to move from their position. }\end{array}\end{array}$

Handling of tools. Any tool activity, e.g. mounting, fixing, preparing, holding tools; walking with a forklift, adjusting car lift, fixing gloves

Indirect Necessary handling work non-VAW (IW)
Handling of parts. Placing a part in the stock, manual inspection of parts, placing parts on the forklift; packing

Administration. ${ }^{\text {a }}$ Writing notes on car parts; placing labels on parts; writing numbers on cars; 


\begin{tabular}{|c|c|c|c|}
\hline & & & visual and manual inspection of cars \\
\hline & & & Walking. Walking without handling anything \\
\hline & & Casual & $\begin{array}{l}\text { Communicating. Two or more workers } \\
\text { discussing issues related to the work }\end{array}$ \\
\hline & & & $\begin{array}{l}\text { Cleaning. Preparation of the workplace; cleaning } \\
\text { at the end of the workday; spreading sawdust; } \\
\text { trashing materials }\end{array}$ \\
\hline & & Unplanned & $\begin{array}{l}\text { Waiting and looking. Waiting for a car to be } \\
\text { placed on a lift, looking for things (tools, phone, } \\
\text { parts, etc.) }\end{array}$ \\
\hline Disturbances & $\begin{array}{l}\text { necessary } \\
\text { non-VAW }\end{array}$ & breaks & $\begin{array}{l}\text { Pauses. Smoking, phone call making coffee, } \\
\text { cleaning and drying the hands (after gasoline, oil, } \\
\text { etc.), talking to co-workers }\end{array}$ \\
\hline & & $\begin{array}{l}\text { Line } \\
\text { transport }\end{array}$ & $\begin{array}{l}\text { Waiting. Time for the line to move the cars } \\
\text { between the disassembly stations }\end{array}$ \\
\hline
\end{tabular}

a In the traditional system "Administration" also included tasks such as computer work, printing labels for registration of parts, which were not activities in the serial-flow system.

\subsubsection{Instrumented recordings}

Task specific posture and movement data were collected during an ordinary working day by means of direct technical measurements in both assembly systems. Inclinometers (Logger Teknologi HB, Åkarp, Sweden) were used for recording the inclinations of the head and the trunk, as well as the elevations of the upper arms (regardless of direction) in relation to the line of gravity (Hansson et al., 2006). The inclinometers were attached to the skin on the forehead, the right side of the thoracic spine and on the lateral side of the upper arms, with double adhesive tape (Hansson et al., 2001). Biaxial electrogoniometers (XM65, Biometrics Ltd, Newport, UK) were used to record wrist flexion/extension and wrist deviation in relation to the neutral wrist angle (Hansson et al., 1996). The goniometer end-blocks were attached to the skin on the distal dorsal forearm and on the back of the hand. The inclinometer and goniometer signals were sampled at $20 \mathrm{~Hz}$ and stored on data loggers (Logger Teknologi HB, Åkarp, Sweden), carried by the subjects.

Locomotion during work was assessed by a pedometer attached to the waist (Fitty 3 Electronic, Uttenreuth, Germany) per the methodology of Selin and Winkel (1994). It 
counted the number of steps taken during the entire work period.

The cardiovascular load was estimated by heart rate recordings during the whole session using a telemetric electrocardiographic system (Polar Vantage NV тм, Polar Electro Oy, Kempele, Finland), logging an average value every $5^{\text {th }}$ second. The heart rate ratio (HRR) was calculated as:

$\mathrm{HRR}=100 *\left(\mathrm{HR}_{\text {work }}-\mathrm{HR}_{\text {rest }}\right) /\left(\mathrm{HR}_{\max }-\mathrm{HR}_{\text {rest }}\right)$

where $\mathrm{HR}_{\text {work}}, \mathrm{HR}_{\text {rest }}$ and $\mathrm{HR}_{\max }$ are mean heart rate during work, heart rate during rest and maximal heart rate, respectively. $\mathrm{HR}_{\text {rest }}$ was assessed by the subject in the morning before getting out of bed and $\mathrm{HR}_{\max }$ was calculated based on age according to Bruce et al., (1974) as $\mathrm{HR}_{\max }=210-0.662 *$ age.

\subsubsection{Data Collection Procedure}

The inclinometers and goniometers were fastened and connected to the loggers and the operators were asked to perform a number of poses for calibration purposes, according to Hansson et al., $(1996,2001)$. The total duration of this calibration procedure was approximately 30 minutes. The recordings during breaks were included in locomotion and cardiovascular data, but excluded from the analyses of the postural data.

\subsection{Data analyses}

\subsubsection{Signal processing}

Goniometer and inclinometer data were transferred from the loggers to a computer for analyses. Postures and angular velocities were expressed as $10^{\text {th }}, 50^{\text {th }}$ and $90^{\text {th }}$ percentiles of cumulative distribution functions (Jonsson 1982). Time related parameters, characterising peak load levels and opportunities to recover, were extracted from the inclinometer and goniometer recordings (Table 2) according to Kazmierczak et al., (2005). In the present paper we operationally define the direction of change in mechanical exposure parameters according to potential impact on musculoskeletal disorders (MSD) based on epidemiological evidence (e.g. N.R.C., 2001, Nordander et al., 2013; Svendsen et al., 2004) (Table 2). 
Table 2. Definition of time related parameters for the investigated body parts and indication of how an increase of the parameters affects risk.

\begin{tabular}{|c|c|c|c|c|c|}
\hline & Head & Trunk & $\begin{array}{l}\text { Upper } \\
\text { arms }\end{array}$ & Wrists & Risk \\
\hline $\begin{array}{l}\text { Relative time at } \\
\text { rest }\end{array}$ & $\begin{array}{l}0^{\circ}-20^{\circ} \\
\text { and } \\
<5^{\circ} / \mathrm{s}\end{array}$ & $\begin{array}{l}0^{\circ}-20^{\circ} \\
\text { and } \\
<5^{\circ} / \mathrm{s}\end{array}$ & $\begin{array}{l}<20^{\circ} \text { and } \\
<5^{\circ} / \mathrm{s}\end{array}$ & $\begin{array}{c}-20^{\circ}<\text { flex. }<+20^{\circ} \text { and } \\
<5^{\circ} / \mathrm{s} \text { and } \\
-10^{\circ}<\text { dev. }<+10^{\circ} \text { and }<5^{\circ} / \mathrm{s}\end{array}$ & Reduced \\
\hline $\begin{array}{l}\text { Number of } \\
\text { periods in } \\
\text { neutral position }\end{array}$ & $0^{\circ}-20^{\circ}$ & $0^{\circ}-20^{\circ}$ & $<20^{\circ}$ & $\begin{array}{c}-20^{\circ}<\text { flex. }<+20^{\circ} \text { and } \\
-10^{\circ}<\text { dev. }<+10^{\circ}\end{array}$ & Reduced \\
\hline $\begin{array}{l}\text { Relative time in } \\
\text { extreme positions } \\
\text { a }\end{array}$ & $\begin{array}{l}<0^{\circ} \text { or } \\
>40^{\circ}\end{array}$ & $\begin{array}{l}<0^{\circ} \text { or } \\
>60^{\circ}\end{array}$ & $>60^{\circ}$ & $\begin{array}{c}-60^{\circ}>\text { flex. }>+60^{\circ} \text { or } \\
-10^{\circ}>\text { dev. }>+30^{\circ}\end{array}$ & Increased \\
\hline $\begin{array}{l}\text { Relative time at } \\
\text { low velocity }\end{array}$ & $<5 \%$ s & $<5 \%$ s & $<5^{\circ} / \mathrm{s}$ & $\begin{array}{c}\text { flex. }<5 \% \text { s and } \\
\text { dev. }<5^{\circ} / \mathrm{s}\end{array}$ & Reduced \\
\hline $\begin{array}{l}\text { Relative time at } \\
\text { high velocity }\end{array}$ & $>90^{\circ} / \mathrm{s}$ & $>90^{\circ} / \mathrm{s}$ & $>90^{\circ} / \mathrm{s}$ & $\begin{array}{c}\text { flex. }>90 \% \text { s or } \\
\text { dev. }>60 \% / \mathrm{s}\end{array}$ & Increased \\
\hline
\end{tabular}

a Positive notation for ulnar deviation and negative for radial deviation

b In periods $>3 \mathrm{~s}$

\subsubsection{Statistics}

As several of the parameters were non-normally distributed, group results were described by medians. The Wilcoxon rank sum test was used to compare exposures of the serial-flow assembly study with the corresponding results of the traditional disassembly (Kazmierczak et al., 2005). For these comparisons planned breaks, such as lunch break, were excluded. The statistical calculations were made using MATLAB's Statistics Toolbox (MATLAB R2010b, Mathworks Inc., www.mathworks.com). The level for significant differences was set at $\mathrm{p}<0.05$. Exposure differences between work tasks were analysed for each parameter and body region. Nine pairwise Wilcoxon signed-rank tests were carried out for each exposure 
parameter (five tasks makes $5 * 4 / 2=10$ tests, but the two Disturbance-related tasks; 'unplanned breaks' and 'line transport', per Table 1, were not tested against each other). Significances in the results were indicated as follows:

- A black asterisk was used when a work task was significantly different from all other tasks; for each such finding four (all four tests for that task) of the nine comparisons had to show significantly differences in the same direction.

- A pair of white asterisks was used when two tasks were significantly different from the three other tasks (but not from each other).

\subsection{Simulation of "waste removal” Innovation}

To address RQ2 we conducted a simulation of the removal of non-value added "waste" activities using the task-time and body-kinematic profiles measured on the disassembly line as inputs. According to this, reduced duration of the tasks of 'casual work', 'unplanned breaks', and 'line transport' could be expected targets of future improvement efforts on the serial-flow system. A simulation with decreased duration of these tasks was therefore conducted. The pooled averaged observed relative time in these categories was $18.5 \%$. In the simulation this time was decreased linearly to $0 \%$ with $2 \%$ indicated as a likely practical minimum. The time savings were then distributed across remaining direct work (DW) and indirect work (IW) according to their relative time proportions as measured in the task-level kinematic analysis. This illustrative simulation is reported for the time related parameters of 'relative time at high wrist velocity', 'relative time at low wrist velocity', and 'relative time at wrist rest', as defined in Table 2. These exemplifying variables include both hazard (high wrist velocity) and protective (low wrist velocity) factors associated with repetitive strain type injuries (Nordander et al., 2013).

\section{Results}

Full data sets, i.e. signals without visually identifiable disturbances, were obtained for all subjects for heart rate and number of steps, and for eight of the nine subjects for the logger measurements of posture. Non-dominant arm data was not available from the traditional system, and are thus excluded from the job-level comparison. 


\subsection{Time comparison in serial-flow and traditional systems}

Figure 2 shows the time consumption in per cent for the five different task categories in the serial-flow system, and for comparison, the corresponding data from the study of the traditional system (Kazmierczak et al., 2005). In the latter administrative computer work, such as logging the parts to be sold into the inventory database, was included as 'casual work'.

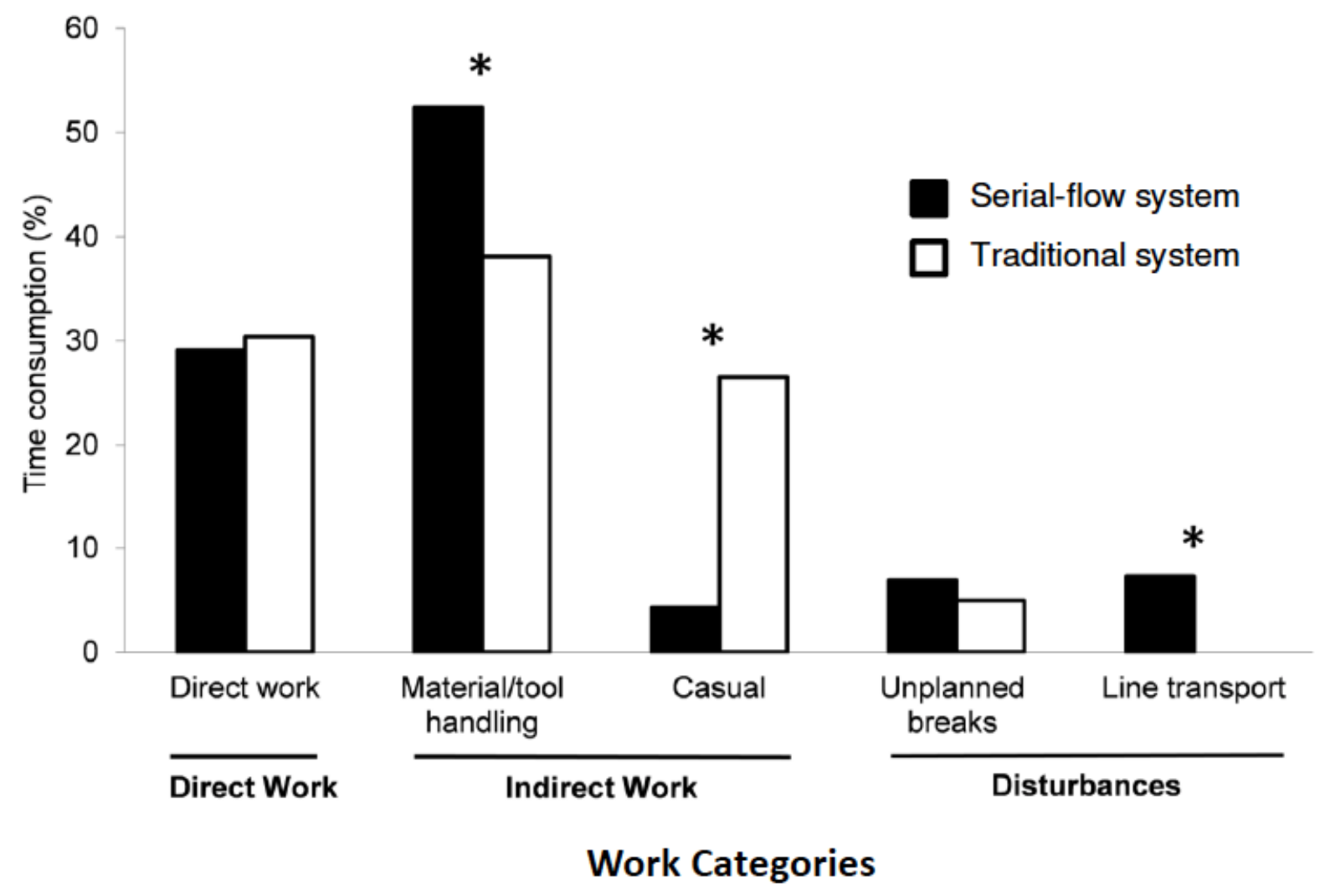

Figure 2. Distribution of task categories (see Table 1) in per cent of the total analysed time from video analyses. Solid bars: serial-flow system $(n=8)$, open bars: traditional system $(n=10)$. Time for line transport occurred only in the serial-flow system. The stars indicate significant differences between the systems.

\subsection{Exposure comparison in serial-flow and traditional systems}

In overview: while the working postures were similar with few significant differences between the systems, the movement velocities in the new line-based system were generally higher with many significant differences. We present variables with typical response patterns in the figures below and provide group medians and ranges of all parameters tabulated in Appendix Tables A1-A6 (see the supplementary file) providing a referent baseline for future 
research in this area.

\subsubsection{Posture}

Among the 24 comparisons, three significant differences indicated higher exposures in the traditional system, and two significant differences indicated higher exposures in the serialflow system. In the $10^{\text {th }}$ percentile of the postures, the traditional system showed significantly higher exposure for the head and trunk, while the serial-flow system did so for wrist deviation. For the $50^{\text {th }}$ percentile, there was a significantly larger forward bending for the trunk in the serial-flow system compared to the traditional $\left(17.2^{\circ}\right.$ vs. $\left.10.1^{\circ}\right)$. Finally, the 'Relative time in extreme positions' for the head was highest for the traditional system $(46.5 \%$ vs. $32.8 \%)$.

\subsubsection{Angular velocity}

The angular velocities were highest in the serial-flow system as indicated by 15 significant differences among 28 comparisons ( 6 parameter, and five body angles, the two wrists angles are combined in 'relative time at rest' and 'relative time at low velocity'). Only two comparisons showed significantly higher velocity in the traditional system indicating increased risk. These both concerned the trunk: 'number of periods in neutral position' (1.5/min for traditional system vs. $2.1 / \mathrm{min}$ for the serial-flow line system), and 'relative time at low velocity' $(0.8 \%$ vs. $2.0 \%)$.

The 15 group medians of the three percentiles $\left(10^{\text {th }}, 50^{\text {th }}\right.$ and $\left.90^{\text {th }}\right)$ for the five compared body parts of angular velocities were all higher in the serial-flow system. Nine (out of ten) of the $50^{\text {th }}$ and $90^{\text {th }}$ percentiles were significantly higher in the serial-flow system (Figure 3 shows the median results). Similarly the 'relative time at high velocity' indicator showed significantly higher exposure for head, arm and wrists in the new serial-flow system. This system also showed significantly decreases in the protective factor 'relative time at low velocity' for the head $(0.8 \%$ for the traditional system and $0.2 \%$ for the serial-flow system). 


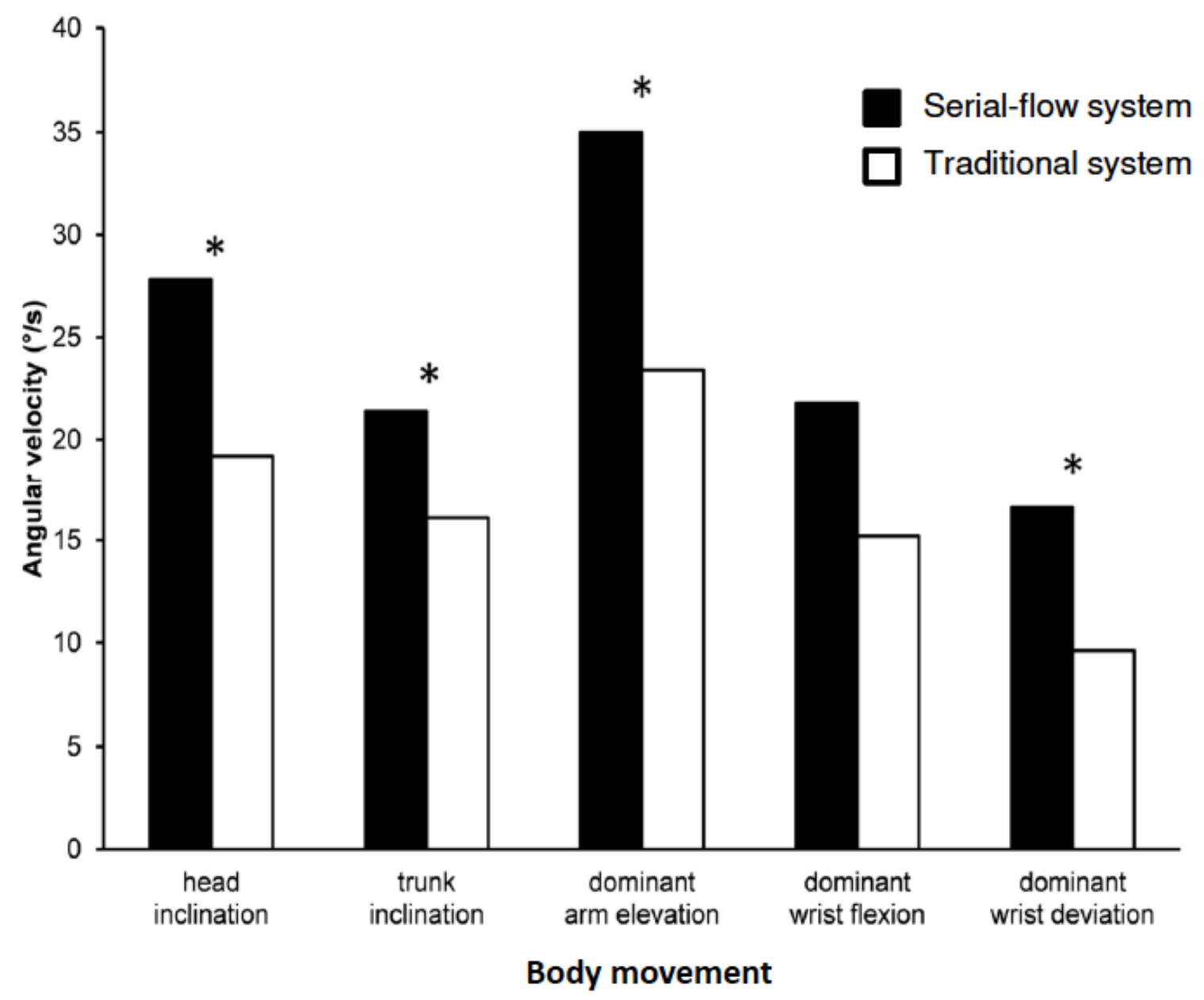

Figure 3. Group median angular velocity $\left(50^{\text {th }}\right.$ percentiles $)$ of the indicated body parts during disassembly in the new serial-flow line system (solid bars, $n=8$ ) and the traditional system (open bars, $n=9$ ). The stars indicate significant differences between the systems.

\subsubsection{Heart rate and number of steps}

The median HRR for the workers in the serial-flow system was $32 \%$, and $31 \%$ for those in the traditional system. The median number of steps per hour was 1853 and 1668, respectively. None of these differences were statistically significant suggesting the whole-body workload in the two systems was about the same.

\subsection{Task-level exposure comparisons in the serial-flow system}

Overall, DW and 'material/tool handling' showed the highest exposures regarding postures as well as motion velocities. Of these two task groups, DW showed consistently higher exposures than 'material/tool handling' for postures, while both task groups were similar 
regarding angular velocity.

\subsubsection{Posture}

The working postures showed generally highest risk-level during DW. In 15 of 29 parameters DW had significantly higher risk-factor level than all of the other tasks. The remaining indicators showed a similar pattern, but without statistically significant differences. Fourteen out of the 18 posture percentiles $\left(10^{\text {th }}, 50^{\text {th }}\right.$, and $90^{\text {th }}$, six body parts $)$ were 'highest' during DW. The difference between DW and the other tasks were especially evident for arm elevations. The 'number of periods in neutral position', a protective factor, occurred less frequently during DW (Figure 4). For both arms the 'relative time in extreme positions' was much longer during DW compared to the other activities.

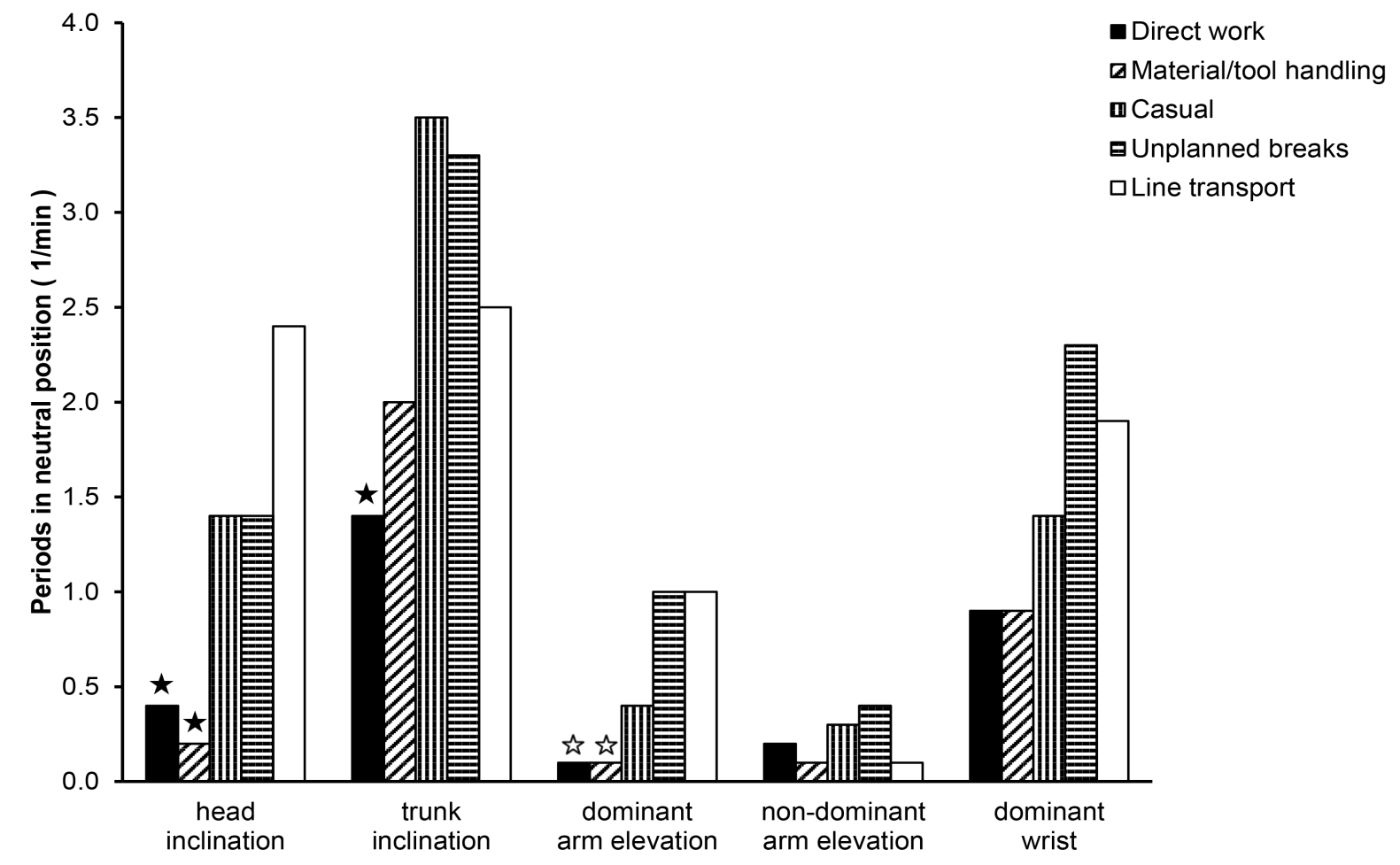

Figure 4. Group medians of the 'Number of periods in neutral postures' - a protective factor $-(\mathrm{n}=8)$ according to task. A black asterisk marks that the task was significantly different from the four other tasks. A pair of white asterisks means that each of those two tasks was significantly different from the three other tasks.

\subsubsection{Angular velocities}

DW and Material/tool handling showed higher exposures than the other three tasks in all group median values of all 34 velocity parameters. The differences for these two tasks were 
statistically significant in 26 of these comparisons. Also, Casual tasks showed higher exposures than the Disturbance-related tasks in 21 of the 34 comparisons. Task exposure differences in velocity parameters are visualized in Figures 5 and 6 for the $50 \%$ ile velocity and relative time at high velocity respectively. Details are presented in the Appendix.

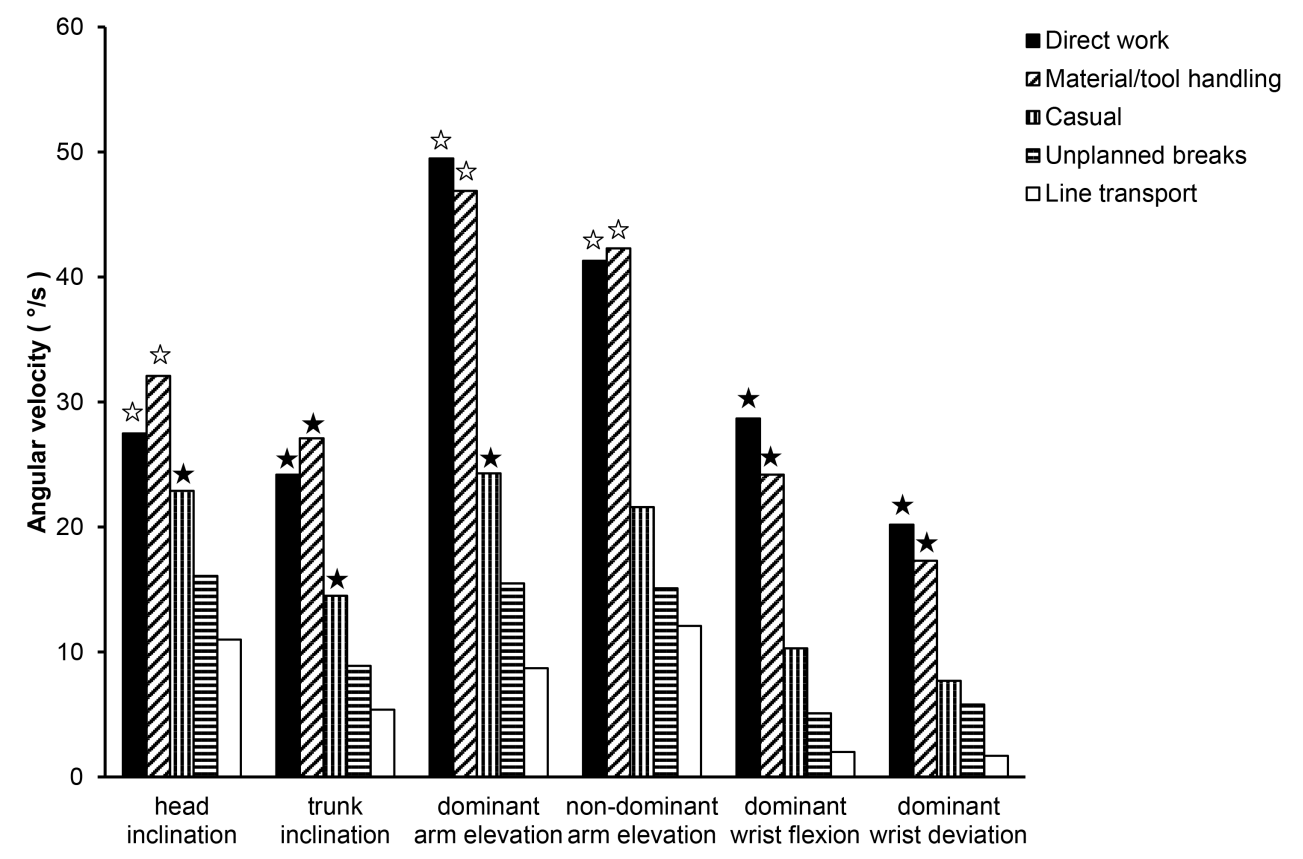

Figure 5. Group medians of $50^{\text {th }}$ percentiles angular velocity $(n=8)$ according to task. A black asterisk marks that the task was significantly different from the four other tasks. A pair of white asterisks means that each of those two tasks was significantly different from the three other tasks.

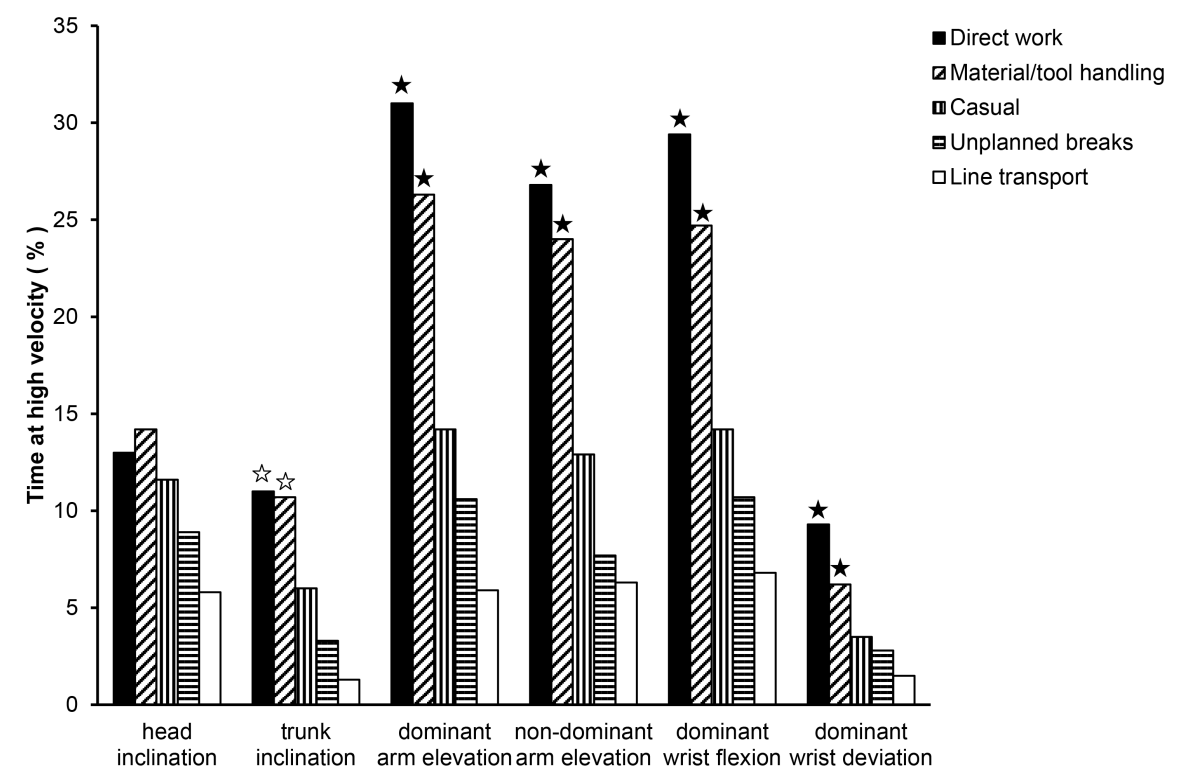

Figure 6. Group medians of 'Relative time at high velocities' $(n=8)$ according to task. A black asterisk marks that the task was significantly different from the four other tasks. A pair 
of white asterisks means that each of those two tasks was significantly different from the three other tasks.

\subsection{Simulation of a "waste removal" innovation}

Figure 7 illustrates how risk at job level will increase according to a simulated tightening of the work based on three different exposure parameters of the dominant wrist. A reduction of 'waste' activities to $2 \%$ was seen as a theoretical maximum and, for this example examining wrist exposures, resulted in increased time at high velocity $(+12 \%)$, decreased time at rest ($28 \%$ ), and decreased time at low velocity $(-77 \%)$ as illustrated in Figure 7 . As reported in section 3.3 above, other kinematic parameters showed similar risk factor trends and simulation would similarly yield both increases in physical risk factor exposure for operators and decreases in protective recovery related times - a two sided increase in RSI risk profile. Results also show that the further the innovation goes in removing waste, the greater the increase in risk for the system operator.

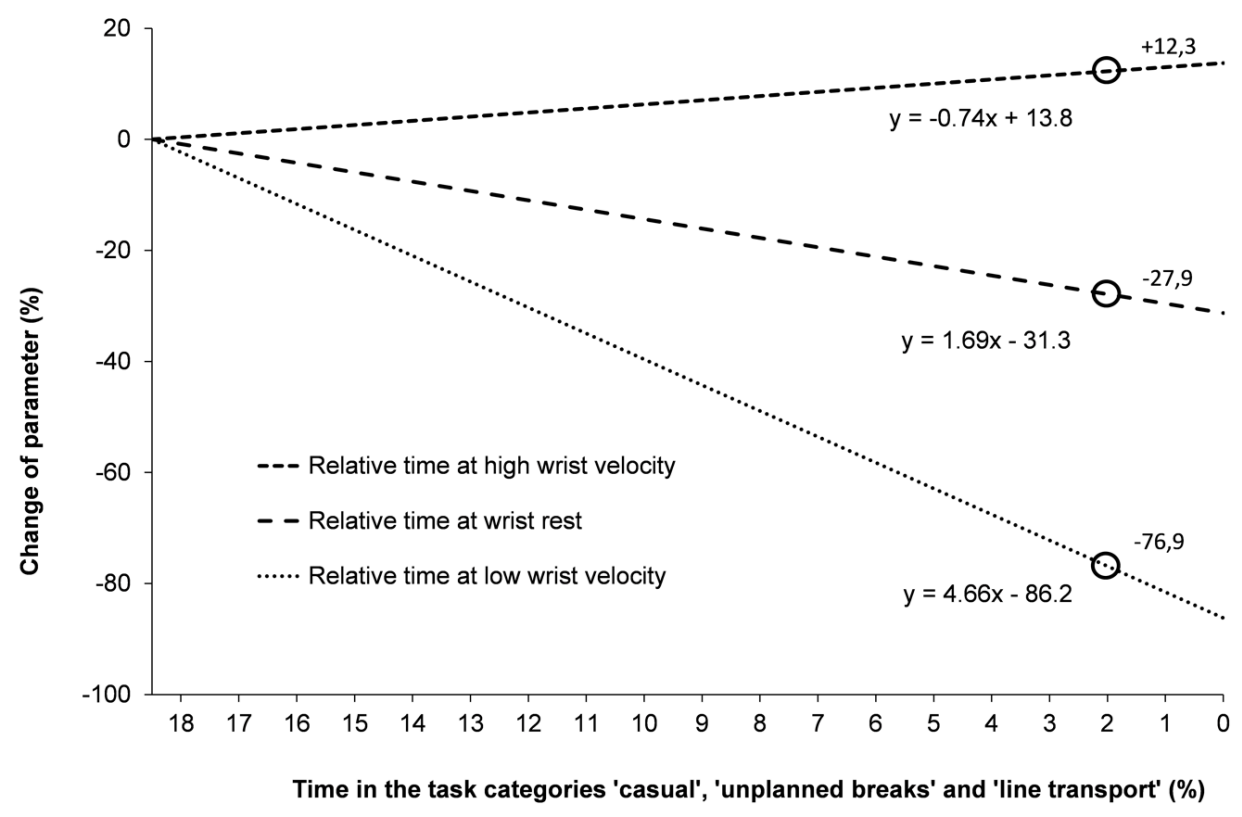

Figure 7. Simulated relative changes from the measured values for the dominant wrist in "time at high velocity", "time at low velocity", and "time at rest" as a function of \%time in the three task categories Casual work, Unplanned breaks, and Line transport as the duration is decrease from the observed $18.5 \%$ to $0 \%$.

\section{Discussion}

In general, the new line-based assembly system had higher movement velocities and less 
recovery time than the traditional parts-recovery system - even though the measured postures were frequently similar. The direct work also showed higher speeds and less recovery time compared to the "waste" tasks; so that removal of waste, a process innovation, resulted in increased movement speeds implying higher injury risk.

\subsection{RQ1: Industrialisation strategy and injury risk}

With regards to RQ1: The new serial-flow system with more complete material recovery had overall higher movement velocities than the traditional system implying higher injury risks for system operators (Nordander et al., 2013; Punnet and Wegman, 2004). This effect appeared to be driven, at least in part, by the elimination of administrative work that was part of the old, more craft production style, car-parts recycling approach. With the operators' work focused more exclusively on the disassembly work, with its higher movement velocities, the physical variation of the job was decreased in the new system as administrative work was performed by another employee in the offices. This is broadly consistent with the increased "division of labor" effects first discussed by Adam Smith (Smith, 1776) at the start of the industrial revolution as production lines were first being developed. This "narrowing" and "intensification" of industrial jobs in line-based production has been criticized by sociotechnical systems researchers (Eijnatten et al., 1993, Clegg, 2000). It is, however, unusual to have objective empirical evidence, as presented here, pointing to a mechanism of injury risk increase that can occur through the innovation process. The main exposure differences concerned dynamic aspects as reflected by the measured movement velocities of body parts, which rarely are captured with observational ergonomics tools that emphasize 'proper posture' (e.g. McAtamney and Corlett, 1994). The long run effect of increasing RSI risks for employees, beyond just the increases in injuries themselves, include decreased quality (Zare et al., 2015), and increases in production costs associated with the direct and indirect costs to the company (Rose et al., 2013; Sobhani et al., 2015). This result is indicative of a potential performance pitfall for innovation engineering projects that ignore the working conditions of system operators.

While it is not possible to generalize from a single case (Yin, 1994), other studies of innovation, for example the implementation of automation (Neumann et al., 2002) or production system design more generally (Neumann et al., 2006; Winkel et al., 2015; Winkel and Westgaard 1996; Westgaard and Winkel, 2011), suggest how innovation efforts may 
affect RSI risks for system operators. While data collected from the old parts-recovery approach is from 2004, this approach remains common today in many countries in very similar configurations to those measured. The old recycling system was optimized to a past legislative and economic environment, while the new line-based system aims at operating profitably in a different, economic context where the full recovery of car materials is becoming increasingly viable. Since the two systems operate with different levels of recycling recovery, our study is less relevant as a comparison at the technical system level than it is a comparison at the higher "industrialization" level - we examine a possible future for this industry and its implications for employee wellbeing (RSI risk). This case comparison study does not prove the generalization "innovation hurts workers" but instead illustrates by example how innovation may negatively affect employee hazards - which in turn can negatively affect performance of the innovation. There are many examples of human factors based innovations yielding positive results for both operators and system performance (Goggins et al., 2008; Neumann and Dul, 2010; Dul and Neumann 2009; Badham and Ehn, 2000) suggesting that better engineering can indeed identify win-win solutions. If engineering teams are to achieve this, however, there is a need for tools, methods, and mandates to support the human factors agenda in the design process (Broberg, 2007; Neumann and Village, 2012; Villaget et. al, 2014; Neumann et al., 2009). The extent to which results here can be transferred directly to a given design case will depend on the similarity of the tasks and movement requirements of the system - like any case study, analytic comparisons are required.

The operator movement velocity increases observed in the new serial-flow disassembly system can be influenced by a number of system design considerations. One key engineering element that can influence our findings here is the means of pace control. In the un-buffered serial-flow disassembly system, all cars were advanced along the line at the same time. This created time pressure for those who had not completed their disassembly tasks on a given car. This imbalance was aggravated by end-of-life vehicles that were in no way standardised for disassembly, and thus caused high time variability and an impulse to rush for different operations. In comparison, the traditional system was self-paced. These examples suggest that contextual factors are important in determining the mechanical exposures and working pace for workers that go beyond the strategic choice of a serial or parallelised flow strategy. Other strategic engineering design choices that can also affect system ergonomics include material supply (or receiving) strategy (Finnsgård et al., 2011; Neumann and Medbo 2010), the use of 
automation (Bainbridge, 1983; Neumann et al., 2002), and the work organisational strategy (Melin 1999; Neumann et al., 2006). Furthermore, in this case of disassembly, failure to attend to disassembly aspects in product design may contribute to higher forces, poorer postures required to reach critical fasteners, and more movement around the vehicle - which in turn would tend to increase mechanical exposures and operational costs in disassembly. The movement around the vehicle, and frequent change of tools required for different disassembly's also contributed to increased time spent in IW, which was considerably higher than a typical assembly factory (Palmerud et al., 2012). Like Design for Manufacturability approaches (Helander and Nagamichi, 1992), improving product disassemble-ability and careful design of the disassembly system could both improve efficiency and also reduce the RSI hazard exposure levels for operators. Studies of product design engineers have shown that recycling and disassembly have been seen as a low priority in design making this an opportunity for further innovation (Kazmierczak et al., 2004). This area poses a research need in the sustainable operations management arena.

\subsection{RQ2: Effects of simulated "Lean" waste removal}

We found that the "waste" activities, targeted for removal in a process innovation approach, were significantly less demanding, and provided more muscular recover opportunity, than the direct work. Thus, simulated waste removal, yielded an expected increase in demands and decrease in recovery for the operators. This finding is consistent with a previous case study in an assembly operation (Palmerud et al., 2012). The amplitude of this effect will depend on the magnitude of the exposure difference between the tasks eliminated and the tasks remaining. We note that this task removal yields a similar 'narrowing' of task diversity to the division of labour effects noted in the system level comparison. It is possible that narrowing the work and increasing task specialisation, which focuses movements on fewer body parts and muscles, is a common factor by which innovation can increase risk for system operators. Our study appears to have isolated a mechanism by which a monolithic "waste removal" interpretation of Lean - a limited but not uncommon distortion of the Toyota Production System - can lead to the increases in musculoskeletal injuries in employees noted in reviews of the empirical research (Landsbergis et al., 1999; Westgaard and Winkel, 2011). Case studies in other sectors have also found that the indirect "waste" tasks in manual work have lower physical demands than the direct work tasks (e.g. Kazmierczak et al.,2005; Jonker et al., 2011; Jonker et al., 2013; Ostensvik et al., 2008; Palmerud et al.,2012). These data support the current findings and are generally consistent with the concept of "work intensification" 
(cf. Hasle et al., 2012, Westgaard and Winkel 2011). The presence of counter-examples of these negative effects of Lean implementations suggests that this is not universal to Lean (e.g. Hasle et al., 2012), but possibly an artefact of lack of attention to HF in the engineering design process. This could be overcome with appropriate engineering management measures (Hasle, 2014; Dabhilkar, 2013; Winkel et al., 2015). Opportunities for operation managers include attention to manufacturability, disassemble-ability and recyclability in product design, better workload and pace management, and the inclusion of job enlargement and job enrichment strategies in production system design.

The simulation for RQ2 illustrate problems with a shallow, binary, approach to the notion of the "value" of tasks. For example the value of 'line transport', which might otherwise be seen as 'waste', could be providing valuable recovery time for operators and thereby avoiding the direct and hidden costs from injury (Rose et al., 2013). Furthermore, this 'waste' time provided an opportunity for operators to assess the incoming vehicle and plan their disassembly strategy, thereby making the next cycle of disassembly more efficient. Under these circumstances we need a more nuanced view of the value embodied by work tasks than the binary view often promulgated under a Lean regime (e.g. Näslund, 2008). If on-going innovation, in this case efforts to eliminate 'waste', increase hazards for operators, then health problems can be expected to increase in this system over time, eventually compromising the planned efficiency gains (Johanson et al., 1993), an effect we call the "Innovation Pitfall" (Glock et al., 2017, Winkel et al., 2017), a parallel to the previously documented "Ergonomic Pitfall": the reduction or elimination of potential risk-reducing effects of ergonomics interventions due to subsequent innovation processes (Winkel and Westgaard 1996). Financial modelling has shown substantial increases in production costs when absenteeism and presenteeism hazards related are considered in cost modelling (Sobhani et al, 2015). This effect could be sustainably avoided by focussing on removal of high workload tasks over low workload tasks, and by applying job enrichment and job enlargement strategies to broaden the variety of physical demands placed on employees during their working day - strategies which have been studied in automotive assembly systems (e.g. Jang et al., 2006). Emphasising efficient performance of necessary work from a human-centred design perspective can thus support more sustainable engineering innovation.

\subsection{Methodological Considerations}

In each of the comparisons made in this study, a large number of variables were compared, 
which may pose a problem for statistical testing. In the comparison of exposure differences between the traditional and serial-flow systems at job level, our conclusions are based on a consistent pattern of significant responses of the dependent variables. Previous studies show that an increase of the wrist angular velocity by 10 degrees/second may imply a 6-percent increase of reported complaints in elbow/hand pain (Nordander et al., 2013); an increase of $1 \%$ in the work-day time with upper arm elevation above 90 degrees implies an increase of the risk of supraspinatus tendinitis by $23 \%$ (Svendsen et al., 2004). Our quantitative objectively measured technical assessments of exposures allow for analysis of velocity and movement based RSI risk factors, which would not have been possible by using observational methods (e.g. Takala et al., 2010; Wells et al., 1997, van der Beek and Frings-Dresen, 1998) or self-reports with this relatively low number of subjects (Winkel and Mathiassen 1994). This study does not cover the full range of risk factors such as psychosocial aspects (Bernard, 1997; Moon and Sauter), which can also be influenced by these innovations (e.g. Neumann, 2009).

\section{Conclusions}

In two nested examples of innovation in a car recycling case study, objective measurements of known risk factors for repetitive strain injury revealed increases in injury risk as a direct result of the innovation process. In the first innovation example, at the level of the industrialization strategy shift from traditional partial parts-recovery to line-based full materials separation, results showed operators to be moving at significantly faster speeds implying higher RSI risk in the new system. Since the body postures, which are determined by layout, were not very different between the systems, the impact of velocity is more related to the organisation of the work process than workstation layout issues. The second, prospective case of innovation, a simulation of a Lean inspired "waste removal" exercise, revealed steady increases in high movement velocities whose demands are associated with RSI, and declines in low velocity time available for muscular recovery - a two-sided increase in risk. The faster more repetitive movements in the direct work activities compared to the "waste" activities drove this risk increase. Engineering managers should attend to human factors as an embedded part of the innovation design process or risk sub-optimal results and injury related costs. Strategies here include careful design of the product, the postures and work pace of the system, as well as the application of job enrichment and enlargement techniques. Research and development work needs to aim at integrating human factors into 
engineering design methodologies to improve the organizational sustainability by improving productivity while avoiding the "innovation pitfall" in which unrecognised increases in employee hazards compromise the performance.

\section{Acknowledgements}

Thanks to the staff and the management at Car Recycling Services, B.V., Dongen, the Netherlands, for facilitating the data collection. Thanks also to Karolina Kazmierczak, Caisa Carlzon-Wessberg, and Olof Persson for assisting in data collection and analysis. This study has received financial support from VINNOVA, project d.nr. 2002-01679, and the former Swedish National Institute for Working Life. One author was also supported by the National Science and Engineering Research Council of Canada (NSERC \#341664).

\section{References}

Anton, D., Weeks, D.L., 2016. Prevalence of Work-Related Musculoskeletal Symptoms among Grocery Workers. International Journal Of Industrial Ergonomics 54: 139-145.

Badham, R., and Ehn, P. (2000). Tinkering with technology: human factors, work redesign, and professionals in workplace innovation. Human Factors and Ergonomics in Manufacturing and Service Industries, 10(1), 61-82.

Bainbridge, L., 1983. Ironies of Automation. Automatica, 19: 775-779.

Barney, J. B., Ketchen, D. J., and Wright, M. (2011). The future of resource-based theory. Journal of Management, 37(5), 1299-1315.

Bernard, M. D. (1997). Musculoskeletal disorders and workplace factors: A critical review of the epidemiologic evidence for work-related musculoskeletal disorders of the neck, upper extremity, and low back. Cincinnati: US Department of Health and Human Services, National Institute for Occupational Safety and Health.

Battini, D., Delorme, X., Dolgui, A., Persona, A., and Sgarbossa, F. (2016). Ergonomics in assembly line balancing based on energy expenditure: A multi-objective model. International Journal Of Production Research, 54(3), 824-845. doi:10.1080/00207543.2015.1074299

Bernard, M.D., 1997. Musculoskeletal Disorders and Workplace Factors: A Critical Review of the Epidemiologic Evidence for Work-Related Musculoskeletal Disorders of the Neck, Upper Extremity, and Low Back. US Department of Health and Human Services, National Institute for Occupational Safety and Health, Cincinnati.

Boudreau, J., Hopp, W., McLain, J.O., Thomas, L.J., 2003. On the Interface between Operations Management and Human Resources Management. Manufacturing and Service Operations Management, 5: 179-202.

Broberg, O., 2007. Integrating Ergonomics into Engineering: Empirical Evidence and Implications for Ergonomists. Human Factors and Ergonomics in Manufacturing 17: 
353-366.

Brook, J.W., Pagnanelli, F., 2014. Integrating Sustainability into Innovation Project Portfolio Management - a Strategic Perspective. Journal of Engineering and Technology Management, 34: 46-62.

Bruce R.A., Fisher L.D., Cooper M N. and Gey G.O., 1974. Separation of effects of cardiovascular disease and age on ventricular function with maximal exercise. American Journal of Cardiology, 34(7): 757-763.

Carter, B., Danford, A., Howcroft, D., Richardson, H., Smith, A. and Taylor, P., 2013. 'Stressed out of My Box': Employee Experience of Lean Working and Occupational Ill-Health in Clerical Work in the Uk Public Sector. Work, Employment and Society, 27: 747-767.

Cherns, A., 1976. The Principles of Sociotechnical Design. Human Relations, 29: 783-792.

Clegg, C.W., 2000. Sociotechnical Principles for System Design. Applied Ergonomics, 31: 463-477.

Dabhilkar, M., Åhlström, P., 2013. Converging Production Models: The STS Versus Lean Production Debate Revisited. International Journal Of Operations And Production Management 33: 3-3.

Docherty, P., Forslin, J., Shani, A.B., 2002. Creating Sustainable Work Systems : Emerging Perspectives and Practice. Routledge, London.

Dul, J., Neumann, W.P., 2009. Ergonomics Contributions to Company Strategies. Applied Ergonomics, 40: 745-752.

Eijnatten, F.M.v., Sitter, U.d., Gustavsen, B., Emery, F., Beinum, H.v., 1993. The Paradigm That Changed the Work Place. Van Gorcum, Arbetslivscentrum, Stockholm.

Elkington, J., 1998. Cannibals with Forks. New Society Publishers, Gabriola Island, BC

Erdinç, O., and Yeow, P. H. P. (2011). Proving external validity of ergonomics and quality relationship through review of real-world case studies. International Journal Of Production Research, 49(4), 949 - 962.

EU, the European Parliament and the Council on end-of-life vehicles, 2000. Directive on endof-life vehicles 2000/53/EC.

Fargnoli, M., De Minicis, M., Tronci, M., 2014. Design Management for Sustainability: An Integrated Approach for the Development of Sustainable Products. Journal of Engineering and Technology Management, 34: 29-45.

Finnsgård, C., Wänström, C., Medbo, L., Neumann, W.P., 2011. Impact of Materials Exposure on Assembly Workstation Performance. International journal of production research, 49: 7253-7274.

Genaidy, A., Karwowski, W. and Shoaf, C, 2002, The Fundamentals of Work System Compatibility Theory: An Integrated Approach to Optimize Human Performance at 
Work, Theoretical Issues in Ergonomics Science, 3 (4), 346-368. 46.

Giri, R., and Kanthababu, M. (2015). Generating complete disassembly sequences by utilising two-dimensional views. International Journal Of Production Research, 53(17), 51185138. doi:10.1080/00207543.2015.1005249

Glock, C. H., Grosse, E. H., Neumann, W. P., and Sgarbossa, F. (2017). Editorial: Human factors in industrial and logistic system design. Computers and Industrial Engineering, 111(Supplement C), 463-466.

Goggins, R.W., Spielholz, P. and Nothstein, G.L., 2008. Estimating the Effectiveness of Ergonomics Interventions through Case Studies: Implications for Predictive CostBenefit Analysis. Journal of Safety Research, 39: 339-344.

Grosse, E. H., Glock, C. H., Jaber, M. Y., and Neumann, W. P. (2014). Incorporating human factors in order picking planning models: Framework and research opportunities. International Journal Of Production Research, 1-23. doi:10.1080/00207543.2014.919424

Güngör, A., and Gupta, S. M. (2002). Disassembly line in product recovery. International Journal Of Production Research, 40(11), 2569-2589. doi:10.1080/00207540210135622

Lacerda, A. P., Xambre, A. R., and Alvelos, H. M. (2016). Applying value stream mapping to eliminate waste: A case study of an original equipment manufacturer for the automotive industry. International Journal Of Production Research, 54(6), 1708-1720. doi:10.1080/00207543.2015.1055349

Hansson G.-Å., Arvidsson I., Ohlsson K., Nordander C., Mathiassen S.E., Skerfving S. and Balogh I., 2006. Precision of measurement of physical workload during standardized manual handling. Part II: Inclinometry of head, upper back, neck and upper arms. Journal of Electromyography and Kinesiology, 16(2): 125-136.

Hansson G.-Å., Asterland P., Holmer N.-G. and Skerfving S., 2001. Validity and reliability of triaxial accelerometers for inclinometry in posture analysis. Medical and Biological Engineering and Computing, 39(4): 405-413.

Hansson G.-Å., Balogh I., Ohlsson K., Rylander L. and Skerfving S., 1996. Goniometer measurement and computer analysis of wrist angles and movements applied to occupational repetitive work. Journal of Electromyography and Kinesiology, 6(1): 2335 .

Hasle, P., Bojesen, A., Jensen, P.L., Bramming, P., 2012. Lean and the Working Environment: A Review of the Literature. International Journal Of Operations And Production Management 32: 829-849.

Hasle, P., 2014. Lean Production — an Evaluation of the Possibilities for an Employee Supportive Lean Practice. Human Factors and Ergonomics in Manufacturing and Service Industries 24: 40-53.

Helander, M., Nagamachi, M., 1992. Design for Manufacturability: A Systems Approach to Concurrent Engineering and Ergonomics. Taylor and Francis, London. 
Hitt, M. A., Xu, K., and Carnes, C. M. (2016). Resource based theory in operations management research. Journal of Operations Management, 41, 77-94.

Huzzard, T., 2003. The Convergence of the Quality of Working Life and Competitiveness - a Current Swedish Literature Review. In: E. Ekstedt (Ed.), Work life in transition, National Insitute for Working Life, Stockholm.

Jang, J.S., Rim, S.C., Park, S.C., 2006. Reforming a Conventional Vehicle Assembly Plant for Job Enrichment. International Journal Of Production Research 44 (4): 703-713.

Jin, J. B., Leem, C. S., and Lee, C. H. (2016). Research issues and trends in industrial productivity over 44 years. International Journal Of Production Research, 54(5), 1273 1284. doi:10.1080/00207543.2015.1064181

Johansson, J., Abrahamsson, L., 2009. The Good Work - a Swedish Trade Union Vision in the Shadow of Lean Production. Applied Ergonomics, 40 (4): 775-780.

Johansson, J.Å., Kadefors, R., Rubenowitz, S., Klingenstierna, U., Lindström, I., Engström, T., Jahansson, M., 1993. Musculoskeletal Symptoms, Ergonomic Aspects and Psychosocial Factors in Two Different Truck Assembly Concepts. International Journal Of Industrial Ergonomics; 12(1): 35-48.

Jonsson, B., 1982. Measurement and evaluation of local muscular strain in the shoulder during constrained work. Journal of Human Ergology, 11(1): 73-88.

Kazmierczak K., 2005. Industrial development of car disassembly - ergonomics and system performance. PhD diss., Lund Institute of Technology and National Institute for Working Life. ISBN 91-628-6595-1, 52 pp.

Kazmierczak K., Mathiassen S.E., Forsman M., Winkel J., 2005. An integrated analysis of ergonomics and time consumption in Swedish 'craft-type' car disassembly. Applied Ergonomics, 36(3): 263-273.

Kazmierczak K., Mathiassen S. E., Neumann W. P., Winkel J., 2006. Observer reliability of industrial activity analysis based on video recordings. International Journal Industrial Ergonomics, 36(3): 275-282.

Kazmierczak, K., Neumann, W.P., Winkel, J., 2007. A Case Study of Serial-Flow Car Disassembly: Ergonomics, Productivity, and Potential System Performance. Human Factors and Ergonomics in Manufacturing 17: 331-351.

Kazmierczak K., Winkel J., Westgaard R. H., 2004. Car disassembly and ergonomics in Sweden: Current situation and future perspectives in light of new environmental legislation. International Journal of Production Research, 42(6): 1305-1324.

Kilker, J., 1999. Conflict on Collaborative Design Teams. IEEE Technology and Society Magazine, 18: 12-21.

Koukoulaki, T., 2014. The Impact of Lean Production on Musculoskeletal and Psychosocial Risks: An Examination of Sociotechnical Trends over 20 Years. Applied Ergonomics, 45: 198-212.

Landsbergis, P.A., Cahill, J., Schnall, P., 1999. The Impact of Lean Production and Related 
New Systems of Work Organization on Worker Health. Journal of Occupational Health Psychology, 4: 108-130.

Leigh, J.P., 2011. Economic Burden of Occupational Injury and Illness in the United States. Milbank Quarterly, 89: 728-772.

Leigh, J.P., Markowitz, S.B., Fahs, M., Shin, C., Landrigan, P.J., 1997. Occupational Injury and Illness in the United States. Estimates of Costs, Morbidity, and Mortality. Arch Intern Med, 157: 1557-1568.

Liker, J.K., 2004. The Toyota Way: 14 Management Principles from the World's Greatest Manufacturer. McGraw-Hill, London.

Longoni, A., Pagell, M., Johnston, D., and Veltri, A. (2013). When does lean hurt? - an exploration of lean practices and worker health and safety outcomes. International Journal Of Production Research, 51(11), 3300-3320

McAtamney, L., Corlett, E.N., 1994. Rula - a Rapid Upper Limb Assessment Tool, Contemporary Ergonomics. Taylor and Francis, London.

Melin B., Lundberg U., Söderlund J., Granqvist M., 1999. Psychological and physiological stress reactions of male and female assembly workers: a comparison between two different forms of work organisation. Journal of Organizational Behavior, 20(1): 4761.

Moon, S. D., and Sauter, S. L. (Eds.). (1996). Beyond biomechanics: Psychosocial aspects of musculoskeletal disorders. London: Taylor and Francis.

Morse, M., Kros, J. F., and Scott Nadler, S. (2009). A decision model for the analysis of ergonomic investments. International Journal Of Production Research, 47(21), 61096128. doi:10.1080/00207540802165809

N.R.C., 2001. Musculoskeletal Disorders and the Workplace: Low Back and Upper Extremities. National Academy Press, Washington DC.

Näslund D., 2008. Lean, six sigma and lean sigma: fads or real process improvement methods? Business Process Management Journal, 14(3): 269-287.

Neumann, W.P., Dul, J., 2010. Human Factors: Spanning the Gap between OM and Hrm. International Journal Of Operations And Production Management, 30: 923-950.

Neumann, W.P., Kihlberg, S., Medbo, P., Mathiassen, S.E., Winkel, J., 2002. A Case Study Evaluating the Ergonomic and Productivity Impacts of Partial Automation Strategies in the Electronics Industry. International journal of production research, 40(16): 40594075 .

Neumann W.P., Medbo L., 2010. Ergonomics and productivity in two material supply concepts: big box vs. Narrow Bins. International Journal of Industrial Ergonomics, 40 (5): 541-548.

Neumann, W.P., Village, J., 2012. Ergonomics Action Research II: A Framework for Integrating Hf into Work System Design. Ergonomics, 55: 1140-1156. 
Neumann, W.P., Wells, R.P., Norman, R.W., Kerr, M.S., Frank, J., Shannon, H.S., OUBPS Working Group, 2001. Trunk Posture: Reliability, Accuracy, and Risk Estimates for Low Back Pain from a Video Based Assessment Method. International Journal Of Industrial Ergonomics, 28: 355-365.

Neumann W.P., Winkel J., Medbo L., Magneberg R., Mathiassen S.E., 2006. Production system design elements influencing productivity and ergonomics - A case study of parallel and serial flow strategies. International Journal of Operations and Production Management, 26(8): 904-923.

Nordander C., Ohlsson K., Åkesson I., Arvidsson I., Balogh I., Hansson G.-Å., Strömberg U., Rittner R., Skerfving S., 2013. Exposure-response relationships in work-related musculoskeletal disorders in elbows and hands - A synthesis of group-level data on exposure and response obtained using uniform methods of data collection. Applied Ergonomics, 44(2): 241-253.

Pagell, M., Klassen, R., Johnston, D., Shevchenko, A., Sharma, S., 2015. Are Safety and Operational Effectiveness Contradictory Requirements: The Roles of Routines and Relational Coordination. Journal of Operations Management, 36: 1-14.

Palmerud G., Forsman M., Neumann W.P., Winkel J., 2012. Mechanical exposure implications of rationalization: a comparison of two flow strategies in a Swedish manufacturing plant. Applied Ergonomics, 43(6): 1110-1121.

Paksoy, T., Güngör, A., Özceylan, E., and Hancilar, A. (2013). Mixed model disassembly line balancing problem with fuzzy goals. International journal of production research, 51(20), 6082-6096. doi:10.1080/00207543.2013.795251

Perrow, C., 1983. The Organizational Context of Human Factors Engineering. Administrative Science Quarterly, 28, 521-541.

Punnett L, Wegman DH. Work-related musculoskeletal disorders: the epidemiologic evidence and the debate. J Electromyogr Kinesiol. 2004;14(1):13-23.

Rose L.M., Orrenius U.E., Neumann W.P., 2013. Work environment and the bottom line: Survey of tools relating work environment to business results. Human Factors and Ergonomics in Manufacturing and Service Industries, 23(5): 368-381.

Selin K., Winkel J., Stockholm MUSIC I study group, 1994. Evaluation of two instruments for recording sitting and standing postures and number of foot steps. Applied Ergonomics, 25(1): 41-46.

Shoaf, C., Genaidy, A., and Karwowski, W. (1998). Comprehensive manual handling limits for lowering, pushing, pulling and carrying activities. Occupational Health and Industrial Medicine, 38(2), 86.

Smith, A., 1776. The Wealth of Nations. Pelican Classics, London.

Sobhani, A., Wahab, M.I.M., Neumann, W.P., 2015. Investigating Work-Related Ill Health Effects in Optimizing the Performance of Manufacturing Systems. European Journal of Operational Research, 241: 708-718.

Spreitzer, G., Porath, C., 2012. Creating Sustainable Performance (Cover Story). Harvard 
Business Review, 90: 92-99.

Svendsen S.W., Bonde J.B., Mathiassen S.E., Stengaard-Pedersen K., Frich L.H., 2004. Work related shoulder disorders: quantitative exposure-response relation with reference to arm posture. Journal of Occupational and Environmental Medicine, 61(10): 844-853.

Takala, E.P., Pehkonen, I., Forsman, M., Hansson, G.-Å., Mathiassen, S.E., Neumann, W.P., Sjøgaard, G., Veiersted, B., Westgaard, R., Winkel, J., 2010. Systematic Evaluation of Observational Methods Assessing Biomechanical Exposures at Work. Scandinavian Journal of Work, Environment and Health 36: 3-24.

Takala, J., Hämäläinen, P., Saarela, K.L., Yun, L.Y., Manickam, K., Jin, T.W., Heng, P., Tjong, C., Kheng, L.G., Lim, S., Lin, G.S., 2013. Global Estimates of the Burden of Injury and Illness at Work in 2012. Journal of Occupational and Environmental Hygiene, 11: 326-337.

Thürer, M., Tomašević, I., and Stevenson, M. (2017). On the meaning of 'waste': Review and definition. Production Planning and Control, 28(3), 244-255.

Van Der Beek, A. J., and Frings-Dresen, M. H. W. (1998). Assessment of mechanical exposure in ergonomic epidemiology. Occupational and Environmental Medicine, 55, 291-299.

Vermeulen, I., Block, C., Van Caneghem, J., Dewulf, W., Sikdar, S.K., Vandecasteele, C., 2012. Sustainability Assessment of Industrial Waste Treatment Processes: The Case of Automotive Shredder Residue. Resources, Conservation and Recycling, 69: 17-28.

Vermeulen, I., Van Caneghem, J., Block, C., Baeyens, J., Vandecasteele, C., 2011. Automotive Shredder Residue (Asr): Reviewing Its Production from End-of-Life Vehicles (Elvs) and Its Recycling, Energy or Chemicals' Valorisation. Journal of Hazardous Materials, 190: 8-27.

Vézina, M., Cloutier, E., Stock, S., Lippel, K., Fortin, É., 2011. Summary Report. Québec Survey on Working and Employment Conditions and Occupational Health and Safety (Eqcotesst). Institut national de santé publique du Québec and Institut de la statistique du Québec, Québec, p. 49.

http://www.inspq.qc.ca/pdf/publications/1356_EnqQuebCondTravailEmpSanteSecTra vail_VA.pdf

Village, J., Greig, M., Zolfaghari, S., Salustri, F., and Neumann, W. P. (2014). Adapting engineering design tools to include human factors. IIE Transactions on Occupational Ergonomics and Human Factors, 2(1), 1-14. doi:10.1080/21577323.2014.905884

Wagner, M., Bachor, V., Ngai, E.W.T., 2014. Engineering and Technology Management for Sustainable Business Development: Introductory Remarks on the Role of Technology and Regulation. Journal of Engineering and Technology Management, 34: 1-8.

Walsh, J.P., Weber, K., Margolis, J.D., 2003. Social Issues and Management: Our Lost Cause Found. Journal of Management, 29: 859-881.

Wells, R., Norman, R., Neumann, W. P., Andrews, D., Frank, J., Shannon, H., and Kerr, M. (1997). Assessment of physical work load in epidemiologic studies: Common 
measurement metrics for exposure assessment. Ergonomics, 40(1), 51-61.

Westgaard, R., Winkel, J., 2011. Occupational Musculoskeletal and Mental Health:

Significance of Rationalization and Opportunities to Create Sustainable Production Systems-a Systematic Review. Applied Ergonomics, 42: 261-296.

Wild R., 1995. Production and Operations Management. Thomson Learning.

Williams, K., Haslam, C., Williams, J., Cutler, T., Adcroft, A., Johal, S., 1992. Against Lean Production. Economy and Society, 21: 320-354.

Winkel J., Edwards K, Birgisdóttir Dröfn B, Gunnarsdóttir S. Facilitating and inhibiting factors in change processes based on the lean tool 'value stream mapping': an exploratory case study at hospital wards. International Journal of Human Factors and Ergonomics. Int. J. Human Factors and Ergonomics, Vol. 3, Nos. 3/4, 2015, 291-302

Winkel, J., Mathiassen, S. E., 1994. Assessment of physical work load in epidemiologic studies: concepts, issues and operational considerations. Ergonomics, 37(6): 979-988.

Winkel, J., Westgaard, R.H., 1996. Editorial: A Model for Solving Work Related Musculoskeletal Problems in a Profitable Way. Applied Ergonomics, 27: 71-77.

Yin, R. K. (1994). Case study research - design and methods (2 ed. Vol. 5). London: Sage.

Zare, M., Croq, M., Hossein-Arabi, F., Brunet, R., Roquelaure, Y., 2015. Does Ergonomics Improve Product Quality and Reduce Costs? A Review Article. Human Factors and Ergonomics in Manufacturing and Service Industries. 


\section{Appendices A1-A6}

The following tables offers a detailed presentation of biomechanical exposure levels in terms of postures and movements, to allow future research teams access to the data for comparison purposes.

Table A1. Median, maximum and minimum inclination and joint angle of the investigated body parts during disassembly work in the tradition and serial-flow systems.

\begin{tabular}{|c|c|c|c|c|c|c|c|}
\hline \multirow[t]{2}{*}{ Disassembly system } & & \multicolumn{3}{|c|}{ Traditional } & \multicolumn{3}{|c|}{ Serial flow } \\
\hline & & median & $\min$ & $\max$ & median & $\min$ & $\max$ \\
\hline \multicolumn{8}{|l|}{ Head $^{\mathrm{a}}$} \\
\hline \multirow{3}{*}{ Flexion $\left({ }^{\circ}\right)$} & $10^{\text {th }}$ & -13.7 & -22.0 & -0.2 & -1.7 & -4.6 & 2.4 \\
\hline & $50^{\text {th }}$ & 19.5 & 5.5 & 38.0 & 22.5 & 10.9 & 27.4 \\
\hline & $90^{\text {th }}$ & 53.3 & 36.7 & 60.0 & 52.5 & 34.2 & 55.9 \\
\hline \multicolumn{8}{|l|}{ Trunk $^{\text {a }}$} \\
\hline \multirow[t]{3}{*}{ Flexion $\left({ }^{\circ}\right)$} & $10^{\text {th }}$ & -6.0 & -11.5 & -0.1 & 5.6 & -5.5 & 9.3 \\
\hline & $50^{\text {th }}$ & 10.1 & 0.3 & 12.3 & 17.6 & 7.1 & 23.1 \\
\hline & $90^{\text {th }}$ & 40.2 & 37.4 & 59.0 & 42.9 & 30.3 & 56.1 \\
\hline \multicolumn{8}{|l|}{ Upper arm dominant side } \\
\hline \multirow[t]{3}{*}{ Elevation $\left({ }^{\circ}\right)$} & $10^{\text {th }}$ & 13.9 & 8.5 & 24.3 & 15.4 & 11.5 & 19.4 \\
\hline & $50^{\text {th }}$ & 32.0 & 22.0 & 41.5 & 36.3 & 27.1 & 41.3 \\
\hline & $90^{\text {th }}$ & 72.1 & 52.0 & 79.2 & 74.4 & 64.8 & 88.5 \\
\hline \multicolumn{8}{|l|}{ Upper arm non-dominant side } \\
\hline \multirow[t]{3}{*}{ Elevation $\left(^{\circ}\right)$} & $10^{\text {th }}$ & - & - & - & 15.6 & 11.6 & 23.7 \\
\hline & $50^{\text {th }}$ & - & - & - & 36.4 & 31.1 & 45.3 \\
\hline & $90^{\text {th }}$ & - & - & - & 75.8 & 65.0 & 88.3 \\
\hline \multicolumn{8}{|l|}{ Wrist dominant side ${ }^{b}$} \\
\hline \multirow[t]{3}{*}{ Flexion $\left(^{\circ}\right)$} & $10^{\text {th }}$ & -27.6 & -52.0 & -12.4 & -40.8 & -67.2 & -16.4 \\
\hline & $50^{\text {th }}$ & -5.2 & -15.5 & 3.8 & -13.1 & -25.6 & 6.0 \\
\hline & $90^{\text {th }}$ & 11.0 & 6.8 & 25.2 & 12.6 & 0.1 & 32.0 \\
\hline \multirow[t]{3}{*}{ Deviation $\left(^{\circ}\right)$} & $10^{\text {th }}$ & -10.8 & -39.0 & -5.6 & $-24.4^{c}$ & $-32.3^{c}$ & $-14.8^{c}$ \\
\hline & $50^{\text {th }}$ & 3.6 & -12.4 & 12.9 & $-5.0^{c}$ & $-16.2^{c}$ & $4.9^{\circ}$ \\
\hline & $90^{\text {th }}$ & 16.3 & 8.5 & 31.1 & $11.2^{\mathrm{c}}$ & $-2.3^{c}$ & $22.9^{c}$ \\
\hline
\end{tabular}

a A positive value indicates forward flexion.

${ }^{\mathrm{b}}$ Positive values indicate palmar flexion, and ulnar deviation, respectively. 
Table A2. Median, maximum and minimum angular velocity of the investigated body parts during disassembly work in the tradition and serial-flow systems.

\begin{tabular}{|c|c|c|c|c|c|c|c|}
\hline \multicolumn{2}{|l|}{ Disassembly system } & \multicolumn{3}{|c|}{ Traditional } & \multicolumn{3}{|c|}{ Serial flow } \\
\hline & & median & $\min$ & Max & median & $\min$ & $\max$ \\
\hline \multicolumn{8}{|l|}{ Head } \\
\hline \multirow[t]{3}{*}{ Flexion $(\% / s)$} & $10^{\text {th }}$ & 2.7 & 2.2 & 3.5 & 3.5 & 1.8 & 5.5 \\
\hline & $50^{\text {th }}$ & 19.2 & 17.0 & 23.7 & 27.8 & 17.6 & 38.7 \\
\hline & $90^{\text {th }}$ & 82.5 & 70.0 & 104.0 & 102.9 & 70.7 & 142.2 \\
\hline \multicolumn{8}{|l|}{ Trunk } \\
\hline \multirow[t]{3}{*}{ Flexion $(\% / s)$} & $10^{\text {th }}$ & 2.0 & 1.3 & 2.4 & 2.0 & 1.1 & 3.7 \\
\hline & $50^{\text {th }}$ & 16.1 & 13.3 & 22.8 & 21.4 & 13.3 & 28.3 \\
\hline & $90^{\text {th }}$ & 74.7 & 64.8 & 86.7 & 86.5 & 63.5 & 100.6 \\
\hline \multicolumn{8}{|l|}{ Upper arm dominant side } \\
\hline \multirow[t]{3}{*}{ Elevation $(\%)$} & $10^{\text {th }}$ & 2.4 & 1.5 & 4.2 & 3.0 & 1.2 & 5.8 \\
\hline & $50^{\text {th }}$ & 23.4 & 18.8 & 35.2 & 35.0 & 19.4 & 49.8 \\
\hline & $90^{\text {th }}$ & 101.0 & 85.4 & 136.2 & 155.8 & 111.6 & 193.8 \\
\hline \multicolumn{8}{|c|}{ Upper arm non-dominant side } \\
\hline \multirow{3}{*}{ Elevation $(\% / s)$} & $10^{\text {th }}$ & - & - & - & 4.0 & 1.3 & 5.2 \\
\hline & $50^{\text {th }}$ & - & - & - & 33.5 & 18.6 & 43.0 \\
\hline & $90^{\text {th }}$ & - & - & - & 139.0 & 101.1 & 168.5 \\
\hline \multicolumn{8}{|l|}{ Wrist dominant side } \\
\hline \multirow[t]{3}{*}{ Flexion $(\% / s)$} & $10^{\text {th }}$ & 1.3 & 0.5 & 1.6 & 1.7 & 0.4 & 2.7 \\
\hline & $50^{\text {th }}$ & 15.2 & 9.5 & 20.6 & 21.8 & 11.1 & 27.5 \\
\hline & $90^{\text {th }}$ & 81.1 & 48.1 & 103.2 & 110.7 & 90.1 & 120.9 \\
\hline \multirow[t]{3}{*}{ Deviation (\%/s) } & $10^{\text {th }}$ & 0.9 & 0.4 & 1.4 & $1.5^{\mathrm{c}}$ & $0.3^{c}$ & $1.8^{\mathrm{c}}$ \\
\hline & $50^{\text {th }}$ & 9.6 & 5.2 & 16.7 & $16.6^{\mathrm{c}}$ & $8.6^{c}$ & $17.9^{\mathrm{c}}$ \\
\hline & $90^{\text {th }}$ & 54.0 & 31.1 & 92.3 & $74.9^{\mathrm{c}}$ & $63.7^{c}$ & $76.7^{c}$ \\
\hline
\end{tabular}


Table A3. Median, maximum and minimum values of five time related parameters of the investigated body parts during disassembly work in the tradition and serial-flow systems.

\begin{tabular}{|c|c|c|c|c|c|c|c|}
\hline \multicolumn{2}{|l|}{ Disassembly system } & \multicolumn{3}{|c|}{ Traditional } & \multicolumn{3}{|c|}{ Serial flow } \\
\hline & & median & $\min$ & $\max$ & median & $\min$ & $\max$ \\
\hline \multicolumn{8}{|l|}{ Head } \\
\hline Rest & $\%$ & 5.0 & 2.7 & 6.8 & 5.9 & 3.0 & 13.2 \\
\hline Neutral position & $\min ^{-1}$ & 0.7 & 0.4 & 1.1 & 0.6 & 0.3 & 1.5 \\
\hline Extreme positions & $\%$ & 46.5 & 39.0 & 58.2 & 32.8 & 24.9 & 41.0 \\
\hline Low velocity & $\%$ & 0.8 & 0.1 & 3.0 & 0.2 & 0.0 & 2.1 \\
\hline High velocity & $\%$ & 6.0 & 5.0 & 9.4 & 12.8 & 5.8 & 21.3 \\
\hline \multicolumn{8}{|l|}{ Trunk } \\
\hline Rest & $\%$ & 9.5 & 4.9 & 21.9 & 14.4 & 7.1 & 21.4 \\
\hline Neutral position & $\min ^{-1}$ & 1.5 & 0.6 & 2.5 & 2.0 & 1.2 & 3.5 \\
\hline Extreme positions & $\%$ & 27.9 & 14.0 & 51.0 & 3.7 & 2.8 & 26.3 \\
\hline Low velocity & $\%$ & 0.1 & 0.0 & 1.3 & 2.3 & 0.3 & 8.8 \\
\hline High velocity & $\%$ & 8.4 & 5.8 & 12.6 & 9.2 & 4.7 & 12.3 \\
\hline \multicolumn{8}{|l|}{ Upper arm dominant side } \\
\hline Rest & $\%$ & 4.0 & 0.5 & 11.5 & 2.2 & 1.7 & 10.7 \\
\hline Neutral position & $\min ^{-1}$ & 0.5 & 0.1 & 1.6 & 0.2 & 0.1 & 0.7 \\
\hline Extreme positions & $\%$ & 15.4 & 6.2 & 22.0 & 18.7 & 12.9 & 28.8 \\
\hline Low velocity & $\%$ & 1.5 & 0.2 & 4.3 & 1.3 & 0.0 & 8.8 \\
\hline High velocity & $\%$ & 12.3 & 8.9 & 20.2 & 22.8 & 13.9 & 30.6 \\
\hline \multicolumn{8}{|c|}{ Upper arm non-dominant side } \\
\hline Rest & $\%$ & - & - & - & 2.0 & 0.6 & 5.7 \\
\hline Neutral position & $\min ^{-1}$ & - & - & - & 0.2 & 0.0 & 0.6 \\
\hline Extreme positions & $\%$ & - & - & - & 19.2 & 13.1 & 27.7 \\
\hline Low velocity & $\%$ & - & - & - & 0.5 & 0.0 & 6.0 \\
\hline High velocity & $\%$ & - & - & - & 19.8 & 12.1 & 26.3 \\
\hline \multicolumn{8}{|l|}{ Wrist dominant side } \\
\hline Rest & $\%$ & 6.5 & 1.5 & 61.2 & 4.9 & 2.4 & 10.7 \\
\hline Neutral position & $\min ^{-1}$ & 1.9 & 0.2 & 3.7 & 1.1 & 0.5 & 1.4 \\
\hline Low velocity & $\%$ & 4.1 & 2.4 & 13.9 & 3.0 & 1.2 & 16.2 \\
\hline \multicolumn{8}{|l|}{ Flexion } \\
\hline Extreme positions & $\%$ & 0.5 & 0.0 & 5.9 & 2.4 & 0.2 & 13.5 \\
\hline High velocity & $\%$ & 8.4 & 2.7 & 12.6 & 23.8 & 8.9 & 27.1 \\
\hline \multicolumn{8}{|l|}{ Deviation } \\
\hline Extreme positions & $\%$ & 34.8 & 7.2 & 89.2 & $37.3^{\mathrm{a}}$ & $19.5^{\mathrm{a}}$ & $72.4^{\mathrm{a}}$ \\
\hline High velocity & $\%$ & 8.3 & 2.9 & 18.4 & $6.9^{\mathrm{a}}$ & $5.7^{\mathrm{a}}$ & $7.3^{\mathrm{a}}$ \\
\hline
\end{tabular}


Table A4. Median, minimum and maximum inclination and joint angle of the investigated body parts for five task categories during disassembly work in the serialflow system. A black asterisk indicates significant differences from all other tasks. A pair of white asterisks indicates that those two tasks are significantly different from the three other bars (but not from each other).

\begin{tabular}{|c|c|c|c|c|c|c|c|c|c|c|c|c|c|c|c|c|}
\hline \multirow[t]{2}{*}{ Task categories } & & \multicolumn{3}{|c|}{ Direct work } & \multicolumn{3}{|c|}{ Material/tool handling } & \multicolumn{3}{|c|}{ Casual } & \multicolumn{3}{|c|}{ Unplanned breaks } & \multicolumn{3}{|c|}{ Line transport } \\
\hline & & median & $\min$ & $\max$ & median & $\min$ & $\max$ & median & $\min$ & $\max$ & median & $\min$ & $\max$ & median & $\min$ & $\max$ \\
\hline \multicolumn{17}{|l|}{ Head $^{\mathrm{a}}$} \\
\hline \multirow[t]{3}{*}{ Flexion $\left(^{\circ}\right)$} & $10^{\text {th }}$ & -3.6 & -8.7 & 2.4 & -0.5 & -5.4 & 3.4 & -2.9 & -6.7 & 0.4 & -3.8 & -6.2 & -0.3 & -0.8 & -2.8 & 1.8 \\
\hline & $50^{\text {th }}$ & $26.7 \star$ & 17.7 & 34.1 & $25.0 \star$ & 10.3 & 26.6 & 13.1 & 8.9 & 18.3 & 13.2 & 6.3 & 26.2 & 12.4 & 5.8 & 21.5 \\
\hline & $90^{\text {th }}$ & 56.1 放 & 42.2 & 60.9 & 52.7 放 & 35.3 & 57.7 & 47.2 & 29.7 & 51.9 & 38.8 & 26.6 & 52.9 & 33.8 & 15.6 & 39.8 \\
\hline \multicolumn{17}{|l|}{ Trunk $^{\mathrm{a}}$} \\
\hline \multirow[t]{3}{*}{ Flexion $\left({ }^{\circ}\right)$} & $10^{\text {th }}$ & 7.7 & -8.8 & 12.1 & 6.0 & -5.0 & 9.6 & 5.1 & -2.1 & 9.0 & 3.6 & -2.7 & 6.6 & 4.1 & -1.2 & 8.1 \\
\hline & $50^{\text {th }}$ & $22.2 \star$ & 7.6 & 36.6 & 16.7 & 6.8 & 24.4 & 13.0 & 6.5 & 19.7 & 10.0 & 4.0 & 17.3 & 10.6 & 6.9 & 16.7 \\
\hline & $90^{\text {th }}$ & $52.3 \star$ & 38.5 & 65.5 is & 42.3 & 29.1 & 54.4 & $37.1 \lesssim$ & 27.9 & 50.5 & 28.4 & 11.9 & 53.7 & 18.2 & 11.5 & 42.7 \\
\hline \multicolumn{17}{|l|}{ Upper arm dominant side } \\
\hline \multirow[t]{3}{*}{ Elevation $\left({ }^{\circ}\right)$} & $10^{\text {th }}$ & $20.7 \star$ & 14.0 & 24.0 & 14.0 & 11.3 & 19.1 & 14.3 & 12.3 & 18.5 & 15.3 & 7.7 & 20.0 & 14.7 & 9.0 & 21.3 \\
\hline & $50^{\text {th }}$ & $48.7 \star$ & 41.8 & 55.1 & 31.6 & 29.8 & 38.6 & 30.4 & 27.3 & 36.9 & 27.9 & 16.1 & 35.1 & 25.1 & 16.1 & 47.2 \\
\hline & $90^{\text {th }}$ & $92.1 \star$ & 80.6 & 101,2 & 68.0 i & 58.8 & 85.0 & 68.7 放 & 50.2 & 80.5 & 53.8 & 38.6 & 70.5 & 49.6 & 27.2 & 75.2 \\
\hline \multicolumn{17}{|c|}{ Upper arm non-dominant side } \\
\hline \multirow[t]{3}{*}{ Elevation $\left({ }^{\circ}\right)$} & $10^{\text {th }}$ & $21.6 \star$ & 15.5 & 28.9 & 14.4 & 10.8 & 22.3 & 13.4 & 10.8 & 22.3 & 14.6 & 7.9 & 25.3 & 17.7 & 10.1 & 22.9 \\
\hline & $50^{\text {th }}$ & $47.5 \star$ & 39.6 & 55,5 & 32.8 & 28.3 & 41.7 & 28.9 & 25.5 & 37.6 & 27.2 & 21.3 & 36,5 & 29.4 & 19.1 & 35.1 \\
\hline & $90^{\text {th }}$ & $89.6 \star$ & 77.3 & 98.5 & 68.6 & 62.8 & 82.6 & 63.1 & 55.2 & 73,9 & 56.5 & 42.1 & 75.1 & 44.3 & 29.6 & 55.0 \\
\hline \multicolumn{17}{|l|}{ Wrist dominant side ${ }^{b}$} \\
\hline \multirow[t]{3}{*}{ Flexion $\left({ }^{\circ}\right)$} & $10^{\text {th }}$ & -43.4 & -68.2 & -16.6 & -39.5 & -58.2 & -16.2 & -47.5 & -75.3 & -17.3 & -30.3 & -78.6 & -16.9 & -33.0 & -68.9 & -12.2 \\
\hline & $50^{\text {th }}$ & -11.8 & -31.2 & 8.4 & -10.4 & -23.2 & 5.4 & -17.8 & -36.7 & 2.9 & -11.4 & -35.5 & 8.6 & -14.0 & -37.3 & -3.4 \\
\hline & $90^{\text {th }}$ & 18.6 & 1.6 & 33.4 & 13.5 & 1.2 & 30.6 & 8.2 & -3.3 & 40.4 & 3.6 & -9.0 & 39.0 & -0.3 & -7.4 & 9.3 \\
\hline \multirow[t]{3}{*}{ Deviation $\left({ }^{\circ}\right)$} & $10^{\text {th }}$ & -24.4 & -31.7 & -13.2 & -23.2 & -32.7 & -14.7 & -24.1 & -41.8 & -10.1 & -17.3 & -21.7 & -6.9 & -14.6 & -31.2 & -8.2 \\
\hline & $50^{\text {th }}$ & -2.4 & -14.0 & 8.6 & -5.4 & -17.9 & 3.8 & -6.1 & -40.5 & 2.2 & -3.9 & -12.5 & -3.1 & -5.6 & -14.5 & 2.5 \\
\hline & $90^{\text {th }}$ & 12.4 & 1.7 & 26.5 & 9.2 & -4.6 & 21.2 & 11.9 & -31.1 & 17.3 & 9.3 & 0.0 & 11.9 & 3.0 & -10.4 & 21.6 \\
\hline
\end{tabular}

a A positive value indicates forward flexion.

b Positive values indicate palmar flexion, and ulnar deviation, respectively. 
Table A5. Median, minimum and maximum angular velocity of the investigated body parts for five task categories during disassembly work in the serial-flow system.

\begin{tabular}{|c|c|c|c|c|c|c|c|c|c|c|c|c|c|c|c|c|}
\hline \multirow[t]{2}{*}{ Task categories } & & \multicolumn{3}{|c|}{ Direct work } & \multicolumn{3}{|c|}{ Material/tool handling } & \multicolumn{3}{|c|}{ Casual } & \multicolumn{3}{|c|}{ Unplanned breaks } & \multicolumn{3}{|c|}{ Line transport } \\
\hline & & median & $\min$ & $\max$ & median & $\min$ & $\max$ & median & $\min$ & $\max$ & median & $\min$ & $\max$ & median & $\min$ & $\max$ \\
\hline \multicolumn{17}{|l|}{ Head $^{\mathrm{a}}$} \\
\hline \multirow[t]{3}{*}{ Flexion $(\%)$} & $10^{\text {th }}$ & $4.0 \star$ & 3.2 & 6.1 & $5.0 \star$ & 3.6 & 6.4 & $2.8 \star$ & 1.8 & 3.7 & 2.1 & 1.2 & 3.7 & 1.5 & 0.8 & 2.2 \\
\hline & $50^{\text {th }}$ & $27.5 \downarrow$ & 21.2 & 40.6 & $32.1 \star$ & 23.8 & 40.6 & $22.9 \star$ & 20.2 & 28.7 & 16.1 & 8.5 & 28.7 & 11.0 & 5.8 & 21.3 \\
\hline & $90^{\text {th }}$ & 104.0 & 71.8 & 156.8 & 108.4 & 79.0 & 138.9 & 98.1 & 77.1 & 120.5 & 84.4 & 56.9 & 120.5 & 63.7 & 31.4 & 98.5 \\
\hline \multicolumn{17}{|l|}{ Trunk $^{\mathrm{a}}$} \\
\hline \multirow[t]{3}{*}{ Flexion $(\%)$} & $10^{\text {th }}$ & $3.1 \star$ & 2.2 & 4.6 & $4.0 \star$ & 2.6 & 4.9 & $1.5 \star$ & 0.9 & 2.3 & 1.1 & 0.5 & 2.3 & 0.7 & 0.3 & 1.4 \\
\hline & $50^{\text {th }}$ & $24.2 \star$ & 18.0 & 31.4 & $27.1 \star$ & 20.2 & 31.0 & $14.5 \star$ & 11.8 & 19.6 & 8.9 & 4.1 & 19.6 & 5.4 & 2.3 & 14.1 \\
\hline & $90^{\text {th }}$ & $94.7 \star$ & 68.5 & 113.8 & $93.2 \star$ & 73.2 & 101.7 & 69.6 & 58.5 & 74.7 & 52.3 & 42.3 & 74.7 & 33.4 & 13.6 & 64.6 \\
\hline \multicolumn{17}{|l|}{ Upper arm dominant side } \\
\hline \multirow[t]{3}{*}{ Elevation $(\% / s)$} & $10^{\text {th }}$ & 6.4 t & 3.8 & 8.6 & $6.7 \hbar$ & 4.2 & 8.5 & 2.2 & 1.0 & 3.3 & 1.3 & 0.8 & 3.3 & 1.0 & 0.4 & 2.0 \\
\hline & $50^{\text {th }}$ & 49.5 & 34.6 & 68.3 & $46.9 \star$ & 32.8 & 56.5 & $24.3 \star$ & 16.1 & 31.4 & 15.5 & 7.8 & 31.4 & 8.7 & 2.7 & 17.8 \\
\hline & $90^{\text {th }}$ & $211.9 \star$ & 154.1 & 286.0 & $161.3 \star$ & 117.2 & 188.7 & 112.3 & 82.3 & 141.9 & 93.1 & 67.5 & 141.9 & 62.0 & 22.7 & 97.6 \\
\hline \multicolumn{17}{|c|}{ Upper arm non-dominant side } \\
\hline \multirow[t]{3}{*}{ Elevation $(\%)$} & $10^{\text {th }}$ & 5.3 t & 3.2 & 9.3 & $5.9 \hbar$ & 4.8 & 9.7 & 2.2 & 1.0 & 3.8 & 1.6 & 0.7 & 3.8 & 1.4 & 0.4 & 3.0 \\
\hline & $50^{\text {th }}$ & $41.3 \hbar$ & 32.8 & 64.7 & $42.3 \not$ & 35.9 & 62.6 & 21.6 & 10.4 & 33.0 & 15.1 & 6.3 & 33.0 & 12.1 & 2.8 & 20.8 \\
\hline & $90^{\text {th }}$ & $185.7 \star$ & 143.5 & 258.3 & $151.9 \star$ & 126.4 & 206.3 & 104.5 & 67.3 & 150.6 & 78.7 & 68.5 & 150.6 & 70.1 & 22.9 & 95.4 \\
\hline \multicolumn{17}{|l|}{ Wrist dominant side } \\
\hline \multirow[t]{3}{*}{ Flexion $(\% / s)$} & $10^{\text {th }}$ & 2.8 t & 1.8 & 4.6 & $2.6 \longleftarrow$ & 1.5 & 3.1 & 0.7 & 0.2 & 1.3 & 0.3 & 0.0 & 1.3 & 0.1 & 0.0 & 0.5 \\
\hline & $50^{\text {th }}$ & $28.7 \star$ & 21.0 & 36.3 & $24.2 \star$ & 17.3 & 27.5 & 10.3 & 6.3 & 13.0 & 5.1 & 2.0 & 13.0 & 2.0 & 0.9 & 7.4 \\
\hline & $90^{\text {th }}$ & $131.8 \star$ & 115.7 & 140.6 & $112.3 \star$ & 97.6 & 119.5 & 79.9 & 48.7 & 105.7 & 63.5 & 52.8 & 105.7 & 41.3 & 8.8 & 77.3 \\
\hline \multirow[t]{3}{*}{ Deviation $(\% / s)$} & $10^{\text {th }}$ & $2.1 \star$ & 1.5 & 3.4 & $2.1 \star$ & 1.2 & 2.4 & 0.4 & 0.3 & 0.6 & 0.3 & 0.0 & 0.6 & 0.1 & 0.0 & 0.2 \\
\hline & $50^{\text {th }}$ & $20.2 \star$ & 16.1 & 24.9 & $17.3 \star$ & 13.0 & 18.5 & 7.7 & 2.2 & 11.3 & 5.8 & 1.7 & 11.3 & 1.7 & 0.8 & 5.6 \\
\hline & $90^{\text {th }}$ & $86.2 \star$ & 75.1 & 99.3 & $72.4 \star$ & 68.2 & 77.2 & 50.0 & 12.8 & 72.6 & 47.2 & 32.1 & 72.6 & 22.2 & 6.3 & 45.5 \\
\hline
\end{tabular}


Table A6. Median, minimum and maximum values of five time related parameters of the investigated body parts for five task categories during disassembly work in the serial-flow system.

\begin{tabular}{|c|c|c|c|c|c|c|c|c|c|c|c|c|c|c|c|c|}
\hline \multirow[t]{2}{*}{ Task categories } & & \multicolumn{3}{|c|}{ Direct work } & \multicolumn{3}{|c|}{ Material/tool handling } & \multicolumn{3}{|c|}{ Casual } & \multicolumn{3}{|c|}{ Unplanned breaks } & \multicolumn{3}{|c|}{ Line transport } \\
\hline & & median & $\min$ & $\max$ & median & $\min$ & median & median & $\min$ & $\max$ & median & $\min$ & $\max$ & median & $\min$ & $\max$ \\
\hline \multicolumn{17}{|l|}{ Head } \\
\hline Rest & $\%$ & $2.8 \star$ & 1.6 & 6.5 & $3.2 \star$ & 2.3 & 11.1 & 9.9 & 5.3 & 12.6 & 11.1 & 2.3 & 17.0 & 20.3 & 11.5 & 42.6 \\
\hline Neutral position & $\min ^{-1}$ & $0.4 \star$ & 0.1 & 1.4 & $0.2 \star$ & 0.1 & 1.4 & 1.4 & 0.2 & 2.4 & 1.4 & 0.0 & 2.0 & 2.4 & 1.2 & 4.1 \\
\hline Extreme positions & $\%$ & 40.1 & 23.4 & 51.6 & 33.4 & 28.4 & 30.5 & 29.0 & 19.1 & 39.2 & 30.5 & 18.8 & 59.8 & 16.2 & 15.3 & 22.5 \\
\hline Low velocity & $\%$ & 0.0 & 0.0 & 1.8 & 0.0 & 0.0 & 0.0 & 0.0 & 0.0 & 3.3 & 0.0 & 0.0 & 1.0 & 0.6 & 0.0 & 4.5 \\
\hline High velocity & $\%$ & 13.0 & 5.8 & 23.5 & 14.2 & 7.3 & 8.9 & 11.6 & 7.3 & 15.5 & 8.9 & 4.2 & 18.6 & 5.8 & 1.3 & 11.9 \\
\hline \multicolumn{17}{|l|}{ Trunk } \\
\hline Rest & $\%$ & $6.5 \star$ & 2.2 & 10.3 & 7.7 & 5.5 & 31.6 & 18.2 & 11.2 & 26.0 & 31.6 & 15.2 & 48.0 & 49.1 & 23.1 & 67.9 \\
\hline Neutral position & $\min ^{-1}$ & $1.4 \star$ & 0.6 & 2.8 & $2.0 \star$ & 0.8 & 3.3 & $3.5 \star$ & 1.6 & 4.8 & 3.3 & 2.3 & 4.7 & 2.5 & 2.2 & 4.9 \\
\hline Extreme positions & $\%$ & $6.3 \star$ & 3.5 & 32.4 & 3.9 & 2.7 & 1.5 & 4.0 & 0.3 & 18.9 & 1.5 & 0.0 & 22.9 & 0.1 & 0.0 & 13.5 \\
\hline Low velocity & $\%$ & $0.2 \star$ & 0.0 & 1.9 & $0.1 \star$ & 0.0 & 4.7 & $1.9 \star$ & 0.6 & 9.9 & 4.7 & 0.0 & 21.7 & 12.3 & 0.0 & 29.1 \\
\hline High velocity & $\%$ & $11.0 \not{\varkappa}$ & 5.4 & 15.4 & $10.7 \hbar$ & 6.3 & 3.3 & 6.0 & 3.7 & 6.7 & 3.3 & 2.3 & 9.4 & 1.3 & 0.3 & 4.6 \\
\hline \multicolumn{17}{|l|}{ Upper arm dominant side } \\
\hline Rest & $\%$ & $0.9 \hbar$ & 0.4 & 1.8 & 1.8 t & 0.6 & 6.7 & 4.1 & 1.6 & 5.3 & 6.7 & 0.3 & 32.2 & 4.3 & 1.1 & 38.0 \\
\hline Neutral position & $\min ^{-1}$ & $0.1 \star$ & 0.0 & 0.3 & $0.1 \star$ & 0.0 & 1.0 & 0.4 & 0.1 & 0.8 & 1.0 & 0.0 & 2.1 & 1.0 & 0.1 & 3.5 \\
\hline Extreme positions & $\%$ & $35.3 \star$ & 28.1 & 43.6 & 14.0 t & 9.2 & 6.3 & $13.6 \hbar$ & 3.4 & 24.8 & 6.3 & 3.4 & 15.7 & 4.1 & 0.8 & 13.5 \\
\hline Low velocity & $\%$ & 0.0 & 0.0 & 1.8 & 0.0 & 0.0 & 2.5 & 0.7 & 0.0 & 7.2 & 2.5 & 0.0 & 9.9 & 5.0 & 0.0 & 27.3 \\
\hline High velocity & $\%$ & $31.0 \star$ & 21.2 & 41.0 & $26.3 \star$ & 16.3 & 10.6 & 14.2 & 8.4 & 20.5 & 10.6 & 6.0 & 18.0 & 5.9 & 1.2 & 11.3 \\
\hline \multicolumn{17}{|c|}{ Upper arm non-dominant side } \\
\hline Rest & $\%$ & 1.0 & 0.1 & 2.4 & 1.7 & 0.2 & 4.9 & 3.0 & 0.6 & 7.9 & 4.9 & 0.0 & 27.1 & 3.1 & 0.1 & 11.1 \\
\hline Neutral position & $\min ^{-1}$ & $0.2 \star$ & 0.0 & 0.3 & 0.1 & 0.0 & 0.4 & 0.3 & 0.0 & 1.4 & 0.4 & 0.0 & 1.8 & 0.1 & 0.0 & 2.8 \\
\hline Extreme positions & $\%$ & 39.3 & 23.1 & 67.1 & 15.6 & 11.2 & 9.7 & 12.1 & 7.5 & 38.5 & 9.7 & 2.0 & 59.1 & 3.3 & 0.7 & 7.7 \\
\hline Low velocity & $\%$ & 0.0 & 0.0 & 1.8 & 0.0 & 0.0 & 1.8 & 0.8 & 0.0 & 8.1 & 1.8 & 0.0 & 10.4 & 0.5 & 0.0 & 25.1 \\
\hline High velocity & $\%$ & $26.8 \star$ & 19.9 & 39.0 & $24.0 \star$ & 18.4 & 7.7 & 12.9 & 6.3 & 21.8 & 7.7 & 6.2 & 17.0 & 6.3 & 1.2 & 11.0 \\
\hline \multicolumn{17}{|l|}{ Wrist dominant side } \\
\hline Rest & $\%$ & 2.7 & 1.2 & 5.6 & 3.3 & 2.0 & 25.3 & 7.8 & 0.0 & 22.1 & 25.3 & 0.9 & 42.8 & 23.4 & 0.2 & 70.2 \\
\hline Neutral position & $\min ^{-1}$ & 0.9 & 0.5 & 1.1 & 0.9 & 0.4 & 2.3 & 1.4 & 0.0 & 3.0 & 2.3 & 0.0 & 4.3 & 1.9 & 0.0 & 3.2 \\
\hline Low velocity & $\%$ & $0.5 \star$ & 0.0 & 1.8 & $0.9 \star$ & 0.2 & 19.4 & $8.6 \star$ & 0.0 & 19.8 & 19.4 & 0.0 & 43.1 & 43.3 & 11.1 & 68.4 \\
\hline \multicolumn{17}{|l|}{ Flexion } \\
\hline Extreme positions & $\%$ & 2.8 & 0.1 & 15.3 & 2.5 & 0.2 & 0.8 & 2.2 & 0.0 & 26.7 & 0.8 & 0.0 & 22.5 & 0.3 & 0.0 & 12.0 \\
\hline High velocity & $\%$ & $29.4 \star$ & 23.7 & 33.3 & $24.7 \star$ & 19.4 & 10.7 & 14.2 & 5.1 & 21.4 & 10.7 & 8.7 & 24.3 & 6.8 & 1.0 & 13.7 \\
\hline \multirow{2}{*}{\multicolumn{17}{|c|}{ Deviation }} \\
\hline & & & & & & & & & & & & & & & & \\
\hline Extreme positions & $\%$ & 33.7 & 16.7 & 60.0 & 33.2 & 19.1 & 28.1 & 39.8 & 11.1 & 100.0 & 28.1 & 5.3 & 64.0 & 36.9 & 7.8 & 97.3 \\
\hline High velocity & $\%$ & $9.3 \star$ & 6.6 & 12.0 & $6.2 \star$ & 5.6 & 2.8 & 3.5 & 2.0 & 6.3 & 2.8 & 1.6 & 4.9 & 1.5 & 0.3 & 2.6 \\
\hline
\end{tabular}


